\title{
Impacts of urbanization on groundwater hydrodynamics and hydrochemistry of the Toluca Valley aquifer (Mexico)
}

\author{
M. A. Martín del Campo • M. V. Esteller • \\ J. L. Expósito • R. Hirata
}

Received: 11 February 2013 / Accepted: 23 December 2013 /Published online: 4 March 2014

(C) Springer Science+Business Media Dordrecht 2014

\begin{abstract}
The Toluca Valley is located on the high plains of Mexico, where there are significant industrial zones and large populations. Water needs are almost exclusively met by groundwater, which has brought about intense exploitation of the aquifer and indication of some contamination. The present study investigates the effect of urbanization, related to industrialization of the region, on groundwater in the central portion of the Toluca Valley aquifer-a zone with high population density and where the largest industrial park is located. A general decline in the groundwater level has been found over the years, at a rate of as much as $2.5 \mathrm{~m} /$ year. The appearance of a large drawdown cone was identified, indicating changes in the direction of groundwater flow. Also identified was the presence of several ground fissures, the location of which coincided with the drawdown cone. In hydrochemical terms, the water type is sodium-magnesium bicarbonate and this characteristic has not changed over time, although it has been possible to detect the presence of larger quantities of sulfates (up to $117 \mathrm{mg} / \mathrm{L}$ ) and nitrates (up to $47 \mathrm{mg} / \mathrm{L}$ ) in recent years, likely associated with contamination from industrial and urban wastewater. Factor analysis made it possible to identify ions that
\end{abstract}

M. A. Martín del Campo • M. V. Esteller $(\bowtie) \cdot J$. L. Expósito Centro Interamericano de Recursos del Agua (CIRA), Facultad de Ingeniería, Universidad Autónoma del Estado de México, Cerro Coatepec S/N C.U., 50130 Toluca, Mexico State, Mexico e-mail: mvestellera@uaemex.mx

\section{R. Hirata}

Centro de Pesquisas de Águas Subterrâneas (CEPAS),

Universidade de Sao Paulo, São Paulo, Brazil would characterize natural processes involving the acquisition of salts $\left(\mathrm{HCO}_{3}{ }^{-}, \mathrm{Na}^{+}, \mathrm{Mg}^{2+}\right.$, and $\left.\mathrm{Si}\right)$, as well as anthropic activities $\left(\mathrm{SO}_{4}{ }^{2-}, \mathrm{NO}_{3}{ }^{-}, \mathrm{Cl}^{-}, \mathrm{Ca}^{2+}\right.$, and $\left.\mathrm{K}^{+}\right)$.

Keywords Groundwater - Urbanization · Subsidence · Pollution $\cdot$ Factor analysis

\section{Introduction}

Migration from rural to urban zones leads to a series of social, economic, political, and natural impacts (Corniello et al. 2007). Those that are more easily identified are associated with expansion of the urban footprint and increased demand for resources in order to satisfy the needs of populations settled in these areas. One of the resources most in demand is water (Carlson et al. 2011), which can come from surface as well as ground sources.

It is important to mention that large cities depend mainly on groundwater, for example, Dhaka, Bangladesh (Morris et al. 2003), Delhi, India (Dash et al. 2010), Hong Kong, China (Jiao et al. 2008), and Seoul, South Korea (Choi et al. 2005), among others. This has led to intense exploitation of aquifers, bringing about significant changes in flow regime and groundwater quality (Naik et al. 2008; Howard 2007). In Mexico, clear examples of groundwater dependency include Mexico City (Carrera-Hernández and Gaskin 2007; Ramos-Leal et al. 2010), Querétaro (GutiérrezCarrillo et al. 2002), and San Luís Potosí (CarrilloRivera et al. 2008). 
The urbanization phenomenon occurring in these cities impacts water resources in several ways, for example, impermeabilization of aquifer recharge areas, subsidence, modification of the course of rivers, variations in water level of surface bodies of water and aquifers, water contamination, etc. (Jeong 2001; Carrillo-Rivera et al. 2008; Carlson et al. 2011; Foster et al. 2011). In the case of water contamination, it is important to consider that an increase in population also produces an increase in the volume of wastewater generated, which may be discharged into surface bodies of water or, in many cases, directly into the soil, due to insufficient sewer network coverage. Also important is the fact that, even when a sewer network exists, it may have leaks, which also contaminate groundwater (Naik et al. 2008; Leung et al. 2004).

An example of this problem is the Toluca Valley aquifer, located in the high plains region of Mexico. This zone is subject to a process of industrialization and accelerated population growth; the intensity of these phenomena has been very high since the 1980s. This growth in both population and productive activities has created a high demand for water, which is almost entirely met by groundwater. Intense extraction of groundwater has led to a significant decline in groundwater levels, subsidence and ground-fissuring processes, desiccation of springs and lagoons, as well as a decrease in river flow volume. In addition to these negative results, which have been determined in previous studies (Esteller and Díaz-Delgado 2002; Calderhead et al. 2011), mention should also be made of degradation of groundwater quality due to increased salinity and higher concentrations of certain metals ( $\mathrm{Fe}$ and $\mathrm{Mn})$ and nutrients $\left(\mathrm{NO}_{3}\right)$ (Esteller and Andreu 2005; Esteller et al. 2012).

A large percentage of groundwater extraction is concentrated in the central portion of the Metropolitan Zone of the City of Toluca (MZCT), the fifth largest in Mexico (INEGI 2004). This zone also includes the two largest population centers in the valley- the municipalities of Toluca and Metepec. In addition, this central portion contains a large industrial network with diverse industries, including food, pharmaceutical, automotive, beverage, and paint plants, among others (INEGI 2009).

Therefore, the objective of this study is that of identifying how the urban zone has grown and how groundwater levels behave as a consequence, as well as physical-chemical changes in water that may have occurred in this central portion of the aquifer, where the MZCT is located.

\section{Description of the study area}

The Toluca Valley aquifer is located in the central portion of the State of Mexico, covering an area of $2,738 \mathrm{~km}^{2}$ (Fig. 1a). Identified within this region is a plain that covers $700 \mathrm{~km}^{2}$, with a major axis running north-south for $35 \mathrm{~km}$ and a minor axis running eastwest for approximately $20 \mathrm{~km}$, at an altitude of 2,570 masl. Bordering this plain, there is a series of mountainous elevations, with the La Guadalupana Volcano (3,360 masl) and the El Águilar and Monte Alto mountain ranges to the north, the Tenango and Zempoala Volcanoes to the south (3,340 masl), the Las Cruces and Las Iglesias mountains to the east, and the Nevado de Toluca Volcano (4,690 masl) and the Morelos mountain range to the west.

In terms of climate, most of this region is defined as sub-humid temperate $\mathrm{C}(\mathrm{w} 2)(\mathrm{w})$, while the eastnortheast region, which includes the Las Cruces and Monte Alto mountains, has a semi-cold climate of type $\mathrm{C}(\mathrm{E})(\mathrm{w} 2)(w)$; the highest part of the region, Nevado de Toluca, has a high cold climate $(\mathrm{E}(\mathrm{T}) \mathrm{H})$. Total precipitation varies between $1,300 \mathrm{~mm}$ in the highest areas and $800 \mathrm{~mm}$ on the plain, most of which occurs between April and October; the average annual temperature in the plains region is $14^{\circ} \mathrm{C}$, with an average maximum of $17^{\circ} \mathrm{C}$ and minimum of $0{ }^{\circ} \mathrm{C}$.

This aquifer in question is located in the physiographic region known as the Trans-Mexican Neovolcanic Belt, consisting of a corresponding Cenozoic calc-alkaline volcanic strip. The lithological sequence is associated with Oligocene andesites and rhyolites, Miocene andesites, and Quaternary basalts and andesites, as well as pyroclastic and breccia materials, which are abundant in the mountains (Las Cruces mountains and the Nevado de Toluca Volcano) and make up a large part of the fractured aquifer (Fig. 2). On the plain, lacustrine and alluvial sediments were identified, interspersed with volcanic clastic materials (pyroclasts, tuffs, and breccias), comprising the detritic aquifer, which is subject to intense exploitation (Fig. 2). The thickness of the detritic material varies from a few meters at the base of the mountains to over $500 \mathrm{~m}$ in the center of the valley; it is identified as being of Late Pliocene-Quaternary age. This detritic material overlies the basement that consists of rhyolites, andesites, and basalts (CONAGUA 2002). The detritic aquifer is composed of several aquifer units - an upper aquifer primarily composed of alluvial materials, acting as a unconfined or semi-confined aquifer depending on area 


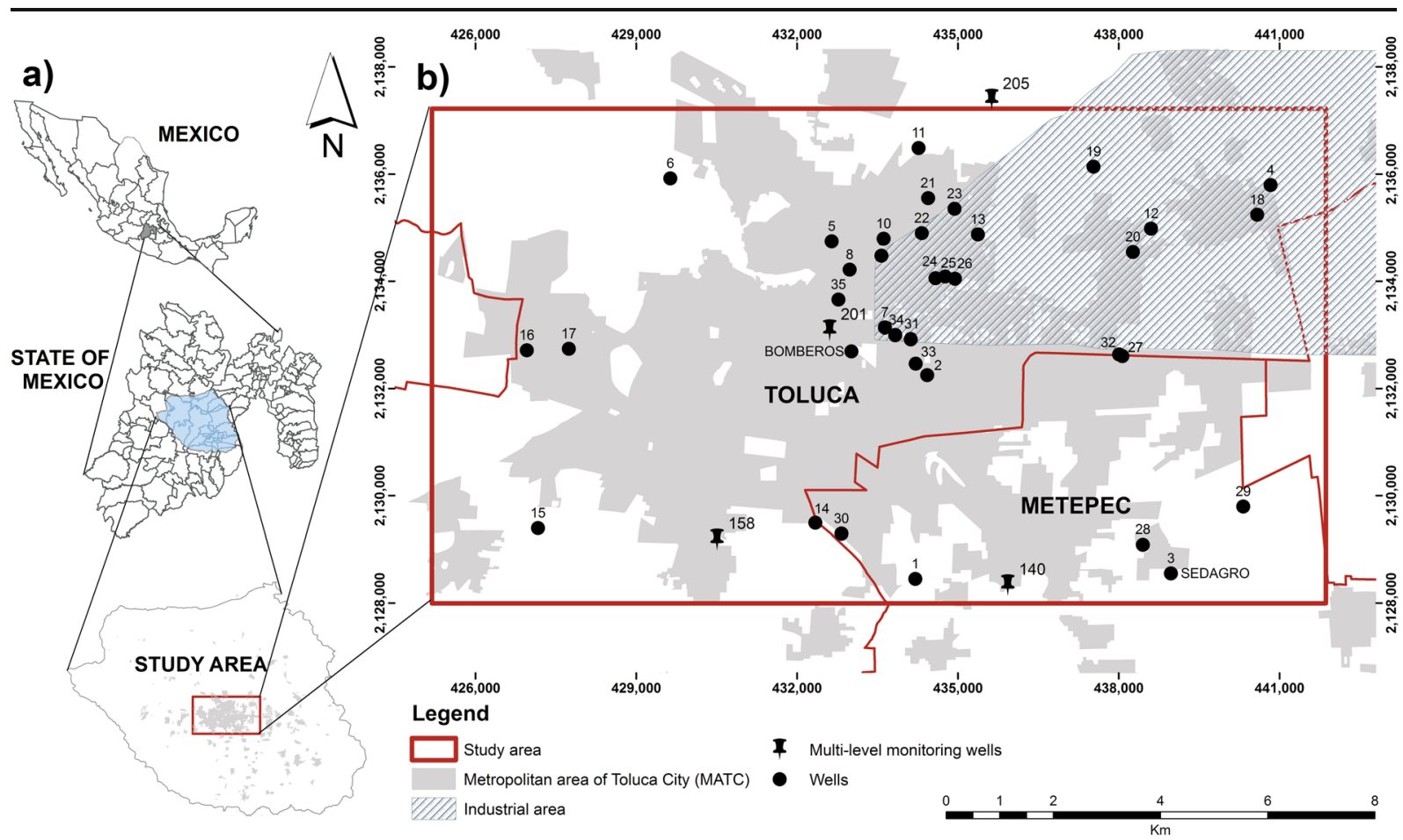

Fig. 1 Map of study area showing a location of study area and $\mathbf{b}$ location of multilevel monitoring wells and sampling wells

(thickness of 0-13 m), and a semi-confined lower aquifer unit, separated from the former by alluvial and pyroclastic layers, as well as fractured volcanic basaltic and andesitic rocks (thickness of 100-400 m). It is important to note that this subdivision is more complex at a detailed level (Calderhead et al. 2011), given that several aquifer units can be defined in certain zones of the aquifer, especially in the central valley, where deposits of interspersed clay and alluvial materials have been identified.

Hydraulic parameters show a wide range of variation, due to the lithological and geometrical variability of the deposits. Nevertheless, it is possible to differentiate zones according to their hydraulic conductivity. In the area of the Alzate Dam, conductivity values vary between 4 and $12 \mathrm{~m} / \mathrm{day}$; in the Almoloya del Río zone, they vary between 40 and $81 \mathrm{~m} /$ day; and in the central zone, they are roughly $4 \mathrm{~m} /$ day (Ariel 1996). The storage coefficient varies between 0.9 and $0.3 \%$ (CCRECRL 1993).

Laterally, the detritic aquifer is primarily recharged from the Nevado de Toluca and Las Cruces mountains and, to a lesser extent, by means of direct infiltration of rainwater. Outlets are mainly associated with underground discharges into the Ixtlahuaca-Atlacomulco Valley and well exploitation.

The Toluca Valley aquifer is subject to intense groundwater exploitation with an extraction rate of
$435.6 \mathrm{hm}^{3} /$ year, versus a recharge rate of $336.8 \mathrm{hm}^{3} /$ year, resulting in a water deficit of $23 \%$ (CONAGUA 2009). Fifty-seven percent of the extracted water is used as a public urban supply for the inhabitants of the Toluca Valley as well as Mexico City, $34 \%$ is for industrial use, and $9 \%$ for agriculture. The water supply for Mexico City is provided by a series of wells known as the Lerma System, which together extract $5.7 \mathrm{~m}^{3} / \mathrm{s}$, though this has reached values as high as $14 \mathrm{~m}^{3} / \mathrm{s}$ (CONAGUA 2005).

Figure 2 shows how demand for groundwater from the Toluca Valley aquifer has grown. Increase in demand began in the 1950s, with extraction of groundwater for providing Mexico City with a supply of drinking water. Later, in the 1970s and 1980s, large industries began to become established, and as a result, there was accelerated immigration and population growth, increasing water demand.

\section{Methods}

The present study focuses on the central portion of the Toluca Valley aquifer, where the MZCT is located, between latitude $19^{\circ} 14^{\prime} 39$ and $19^{\circ} 19^{\prime} 43$ north and longitude $99^{\circ} 42^{\prime} 47$ and $99^{\circ} 42^{\prime} 45$ west, covering roughly $155 \mathrm{~km}^{2}$ with slopes of 0 to $2 \%$ and low hills (Fig. 1). 


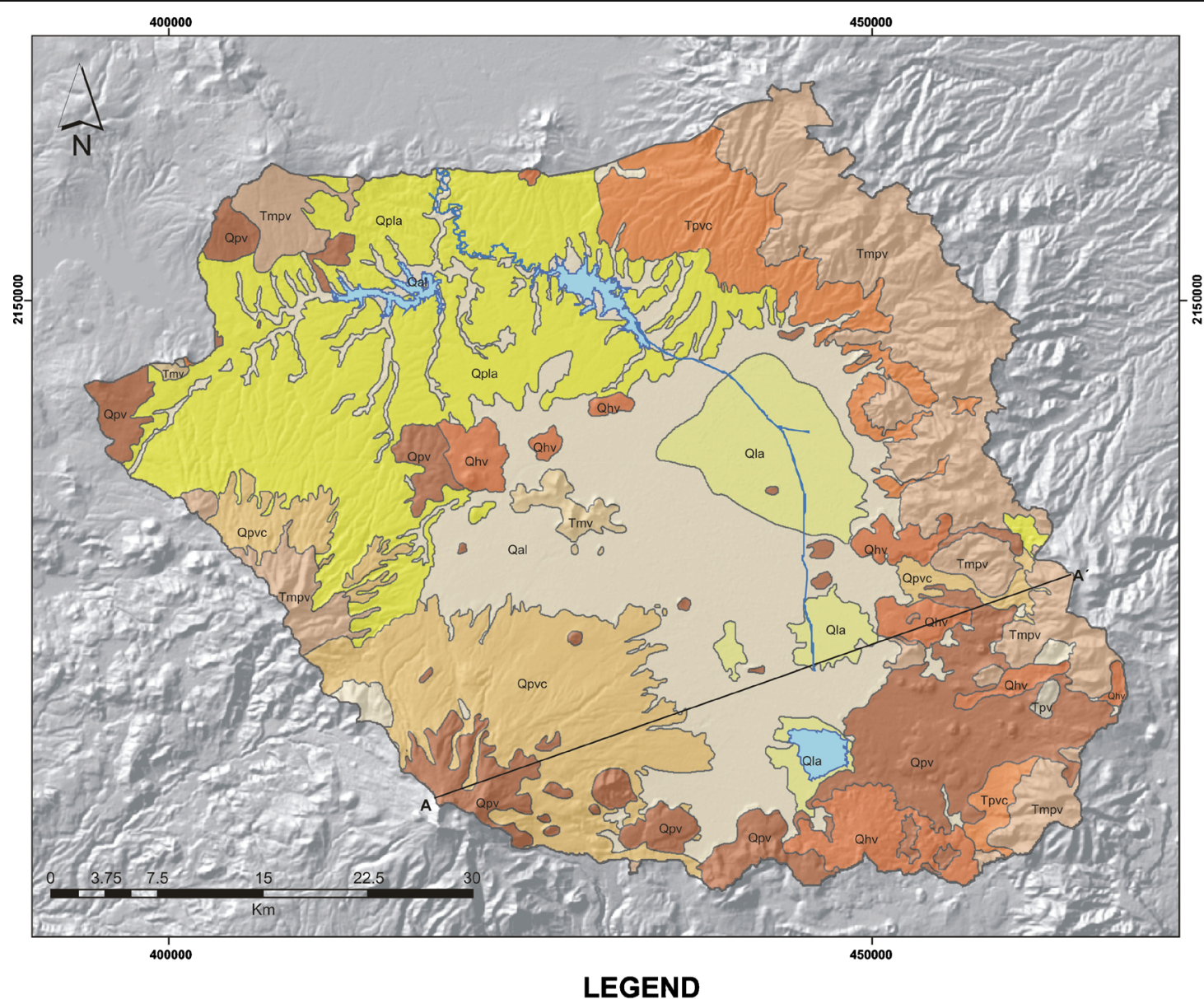

GEOLOGICAL SECTION ALONG LINE A-A'

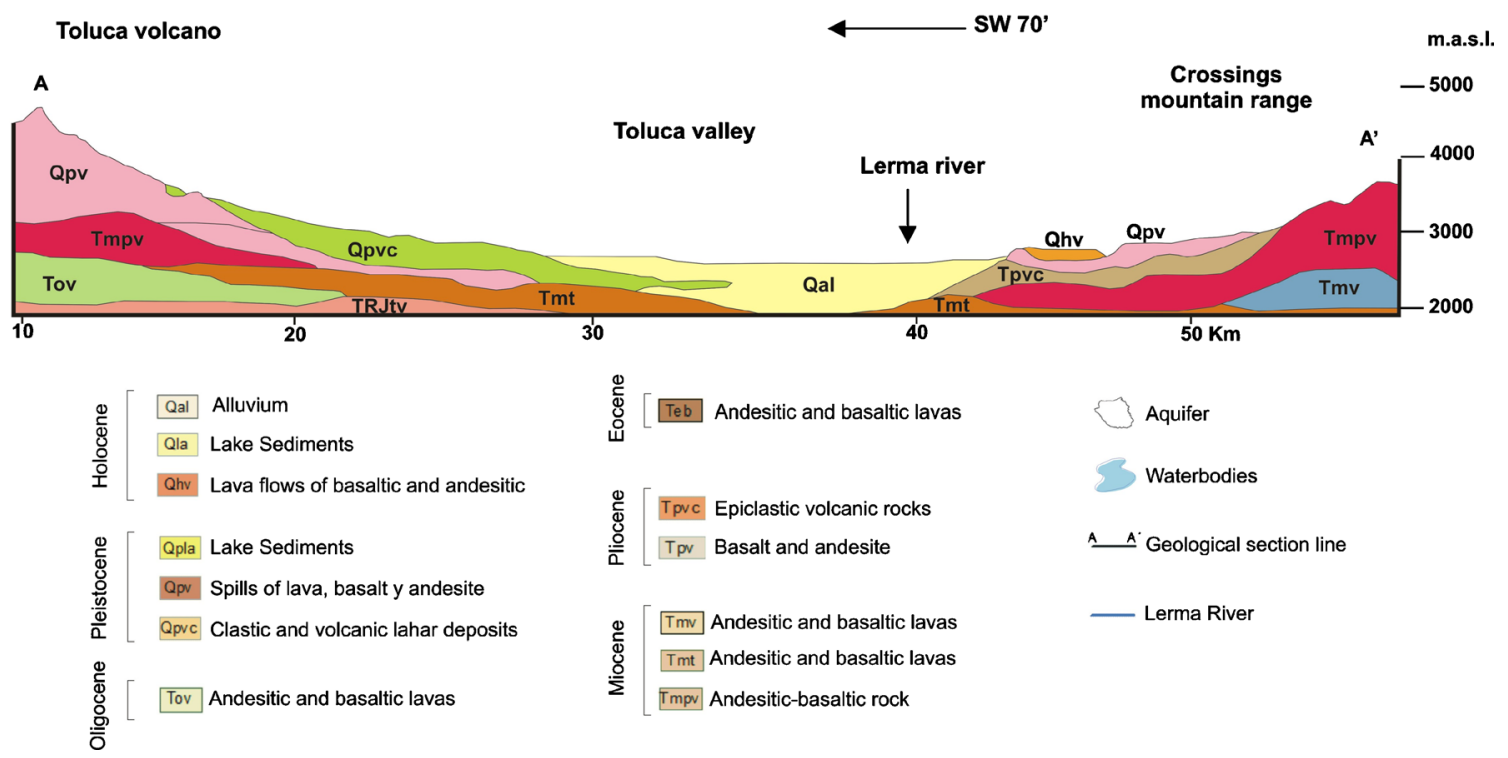

Fig. 2 Geological map of the Toluca Valley, Mexico 
Urban growth

Information on population growth in the municipalities of Toluca and Metepec comes from population censuses taken between 1930 and 2010 by several government entities (Ministry of Industry and Commerce; National Institute of Statistics, Geography and InformaticsINEGI).

Information regarding expansion of the urban zone was obtained from cartography that facilitated settlement of the municipalities of Toluca and Metepec, as well as from the INEGI 2006 database (Census Information Consultation System-SCINCE). Cartographic information for the municipality of Toluca covers the period from 1725 to 2008, whereas for the municipality of Metepec, it covers the period from 1980 to 2008.

\section{Hydrodynamic changes}

In order to determine groundwater extraction volumes, an inventory of pumping wells was consulted. The inventory in question was conducted by the Mexican Institute of Water Technology (IMTA), in collaboration with the National Water Commission (CONAGUA) and published in 2009. This data was supplemented by previous studies (Lesser et al. 1984; CONAGUA 2002), as well as information provided by the City of Toluca Water and Sewage Commission and the Metepec Potable Water, Sewage and Sanitation Company (APAS).

With regard to groundwater levels, the database used contained information from 1968 to 2010 from the network of multilevel monitoring wells installed in the Toluca Valley. This network comprises 47 multilevel monitoring wells, each of which is equipped with several piezometers (between five and six), installed at different depths (from 10 to $180 \mathrm{~m}$ ). These multilevel monitoring wells were spatially distributed throughout the aquifer; specifically, five were identified in the central portion of the aquifer and 11 in adjacent areas (Fig. 1b). In order to corroborate the location of these points, a field survey was conducted and geographic coordinates with topographic elevations were recorded, given that the databases did not include this information.

Records of groundwater levels were reviewed and used to build up a database that was later exported to a Geographic Information System (GIS) in ARC GIS 9.3. This database included groundwater level measurements for each multilevel monitoring well, as well as certain additional data, for example, geographical coordinates, topographic elevation, code "o" identification and piezometer depths, as well as lithological columns.

Once the database was complete, temporal evolution graphs were generated, plotting groundwater level against year. In addition, with the aid of Arc View 3.2 software (ESRI 1999), contour maps were developed for groundwater levels. The level data used were those obtained from the deepest piezometer in each multilevel monitoring well (150 m, on average). The year 1970 was used as a baseline, or initial year, since it is the year with uniform information recorded in the whole database for all multilevel monitoring wells. The maps were generated using data from all (47) multilevel monitoring wells located in the Toluca Valley.

Interpolation between points was performed using the Spline method (ESRI 1999), assigning such variables as groundwater level, depth of level and decline in level, as well as $z$-values with the number of closest neighbors equal to 12 . As a result, maps were obtained for each of the variables mentioned above. In addition, and with the help of Surfer V.6 software (Golden Software Inc. 1997), interpolation was performed using the kriging method to corroborate the results obtained with Arc View 3.2. Thus, it can be affirmed that the results obtained with each software (Arc View 3.2 and Surfer V.6) are identical.

\section{Ground fissures}

Field surveys were conducted in order to identify fissures and establish some of their characteristics, for example, length and thickness, and to assess the damage caused by the fissures to existing urban infrastructure. In addition, wells located near fissures were identified, in particular those near the fissure known as "San Pedro Totoltepec."

During these surveys, control points defined by the State of Mexico General Civil Defense Department were located that indicate risk zones resulting from the presence of fissures. All of the information obtained was organized in a database that became part of the GIS used in this study.

\section{Hydrochemical changes}

Information regarding the physical-chemical characteristics of groundwater over several years (1991-2009) was obtained by consulting a variety of bibliographical 
sources and databases. In the study area, a total of 54 wells were identified where water analyses had been performed during this period. Those parameters with the most frequently recorded information are as follows: $\mathrm{pH}$, electrical conductivity (EC), total dissolved solids (TDS), $\mathrm{Ca}^{2+}, \mathrm{Mg}^{2+}, \mathrm{Fe}_{\text {Total }}, \mathrm{Mn}_{\text {Total }}, \mathrm{Na}^{+}, \mathrm{K}^{+}, \mathrm{HCO}_{3}{ }^{-}$, $\mathrm{SO}_{4}{ }^{2-}, \mathrm{Cl}^{-}, \mathrm{F}^{-}$, and $\mathrm{NO}_{3}{ }^{-}$, although some showed problems of continuity over time, making it difficult to evaluate their temporal evolution.

In addition, a sampling campaign (35 samples) was conducted in 2010, during which the selection criteria were as follows: (1) proximity to identified ground fissures; (2) sampled at the time of earlier campaigns, for which information was available; and (3) spatial distribution covering the defined study zone.

With a view to measuring field parameters, water was collected in plastic containers that had been previously washed in the laboratory, and water temperature, $\mathrm{pH}$, TDS, and EC were measured using an Orion 5-Star Plus multiparameter meter for temperature and $\mathrm{pH}$ and a Carnis Check Mate 90 conductivity meter for EC. Alkalinity was also determined in the field using the titration method with a $0.05-\mathrm{N} \mathrm{HCl}$ solution.

The water samples were collected according to Boulding (1995) and APHA, AWW, and WEF (2005) protocols and analyzed for major anions $\left(\mathrm{SO}_{4}{ }^{2-}, \mathrm{Cl}^{-}\right.$, $\left.\mathrm{NO}_{3}{ }^{-}\right)$, major cations $\left(\mathrm{Ca}^{2+}, \mathrm{Mg}^{2+}, \mathrm{Na}^{+}\right.$, and $\left.\mathrm{K}^{+}\right)$, and minority elements ( $\mathrm{Fe}, \mathrm{Mn}, \mathrm{Si}$ ), being preserved with nitric acid at a $\mathrm{pH}$ less than or equal to 2 . The samples were stored under refrigerated conditions $\left(4^{\circ} \mathrm{C}\right)$ until analysis. The following determinations were made in the laboratory: nitrates and sulfates using U-UV spectrophotometry, chlorides using volumetric analysis, and $\mathrm{Ca}^{2+}, \mathrm{Mg}^{2+}, \mathrm{Na}^{+}, \mathrm{K}^{+}, \mathrm{Fe}, \mathrm{Mn}$, and $\mathrm{Si}$ with an atomic adsorption spectrophotometer (AAS). The balanced error percentage varied between -6.4 and $9.7 \%$. The difference between original samples and duplicates varied by $\pm 8 \%$.

All the physical-chemical results were evaluated using AquaChem 3.7 software (Waterloo Hydrogeologic 1999). This enabled generation of Stiff and Piper diagrams. In addition, isocontent maps were generated with Arc View 3.2 software (ESRI 1999). The procedure adopted for creating the maps was the same as that used in the groundwater level study, but in this case the $z$ variable represented the values of the physical-chemical parameters studied. Furthermore, the results obtained with Arc View were corroborated with Surfer V.6 software.
Statistical analysis

A factor analysis (FA) was also performed to better understand the hydrochemical data and identify the most significant factors - smaller in number than the amount of samples and measured attributes - that explain variability in the data. Factor analysis provides an average to determine significant relationships between parameters and samples (Jeong 2001). The parameters measured in a physical-chemical analysis are the variables, whereas observations are the analysis of date and different location. It is important to remember that most physical-chemical studies are described by a large number of variables; nonetheless, many may be related, and therefore, duplicate information almost always exists, obscuring explanation of the basic structure of the system. Therefore, FA seeks to substitute these for a few of their functions without losing too much information, thereby better facilitating analysis and interpretation of the data. The FA provides a method to construct new, uncorrelated, and mutually independent variables. Each factor is a linear combination of the original variables. The next step in the analysis is to reduce the contribution of the least significant factors (those with eigenvalues less than 1) and thereby obtain a new group of factors that are extracted by Varimax rotation. Finally, in this study, a model was defined by those factors with eigenvalues greater than 1.0 (Liu et al. 2003).

The variables under consideration were as follows: $\mathrm{CE}, \mathrm{T}^{\mathrm{a}}, \mathrm{HCO}_{3}{ }^{-}, \mathrm{SO}_{4}{ }^{2-}, \mathrm{Cl}^{-}, \mathrm{NO}_{3}{ }^{-}, \mathrm{Ca}^{2+}, \mathrm{Mg}^{2+}, \mathrm{Na}^{+}$, $\mathrm{K}^{+}$, and $\mathrm{Si}$. The calculations were performed using STATGRAPHICS Centurion software.

\section{Results and discussion}

Urban growth

Expansion of the urban zone in the central portion of the Toluca Valley aquifer is a consequence of industrialization and the resulting migratory flow of the population. This has led to construction of large housing units as well as development of the municipality of Metepec in the Metropolitan Zone of the City of Toluca-a phenomenon that is having a significant impact.

The creation of an industrial zone in the eastern part of the City of Toluca was facilitated by acquisition of large areas of land at low cost. In addition, widening of the Mexico City-Toluca highway and the provision of 
such urban services such as drinking water, sewage, and electricity influenced the urban development of the area (GEM 2005a, b). Other factors were the large number of services offered by the municipality of Toluca - education, health, transportation, sports and food markets, among others, as well as increased infrastructure and the widening of roadways (GEM 2005a, b) (Fig. 3).

In the specific case of Toluca, the population grew from 89,895 in 1930 (Ministry of Industry and Commerce 1963) to 819,561 in 2010 (INEGI 2010). In the case of Metepec, the population grew from 13,701 in 1930 (Ministry of Industry and Commerce 1963) to 214,162 in the year 2010 (INEGI 2010). Figure 4 shows how the urban zone has expanded during the period from 1725 to 2008 , demonstrating that most of this growth occurred during the 1980s, primarily in the City of Toluca. In addition, during the 1990s, the municipality of Metepec was developed into the Metropolitan Zone of the City of Toluca.

Hydrodynamic changes

\section{Groundwater extraction}

Groundwater has been exploited in the Toluca Valley aquifer, from its inception (in the 1950s) to the present, principally to meet the needs of the population and industry (Table 1, Fig. 3). In the central portion of the aquifer, 210 wells have been identified, which correspond to $28 \%$ of the 767 wells that exist throughout the entire aquifer (IMTA-CONAGUA 2009), although there may be more wells, as other studies have cited as many as 935 (Calderhead et al. 2011). The main uses of the extracted water are urban and industrial, which represent 57 and $34 \%$, respectively, of the total volume extracted in this central portion of the aquifer (Table 1, Fig. 5). The number of wells designated for each use is a reflection of current demand and, possibly, future demand in the area.

Figure 5 shows the greatest density of wells and the highest pumping rates found in the industrial zone, where the most extensive ground fissures are also identified (San Pedro Totoltepec fissure).

\section{Temporal evolution of groundwater level}

A total of four multilevel monitoring wells were identified in the study zone-PL-140, PL-158, PL-201, and PL-205 (Fig. 1b) - for which groundwater level data are available from 1968 to the present. Lithological columns of these multilevel monitoring wells (Fig. 6) demonstrate the existence of complex interlayering of clay (aquitard) and detritic materials (aquifer) that discriminate between a number of production units and

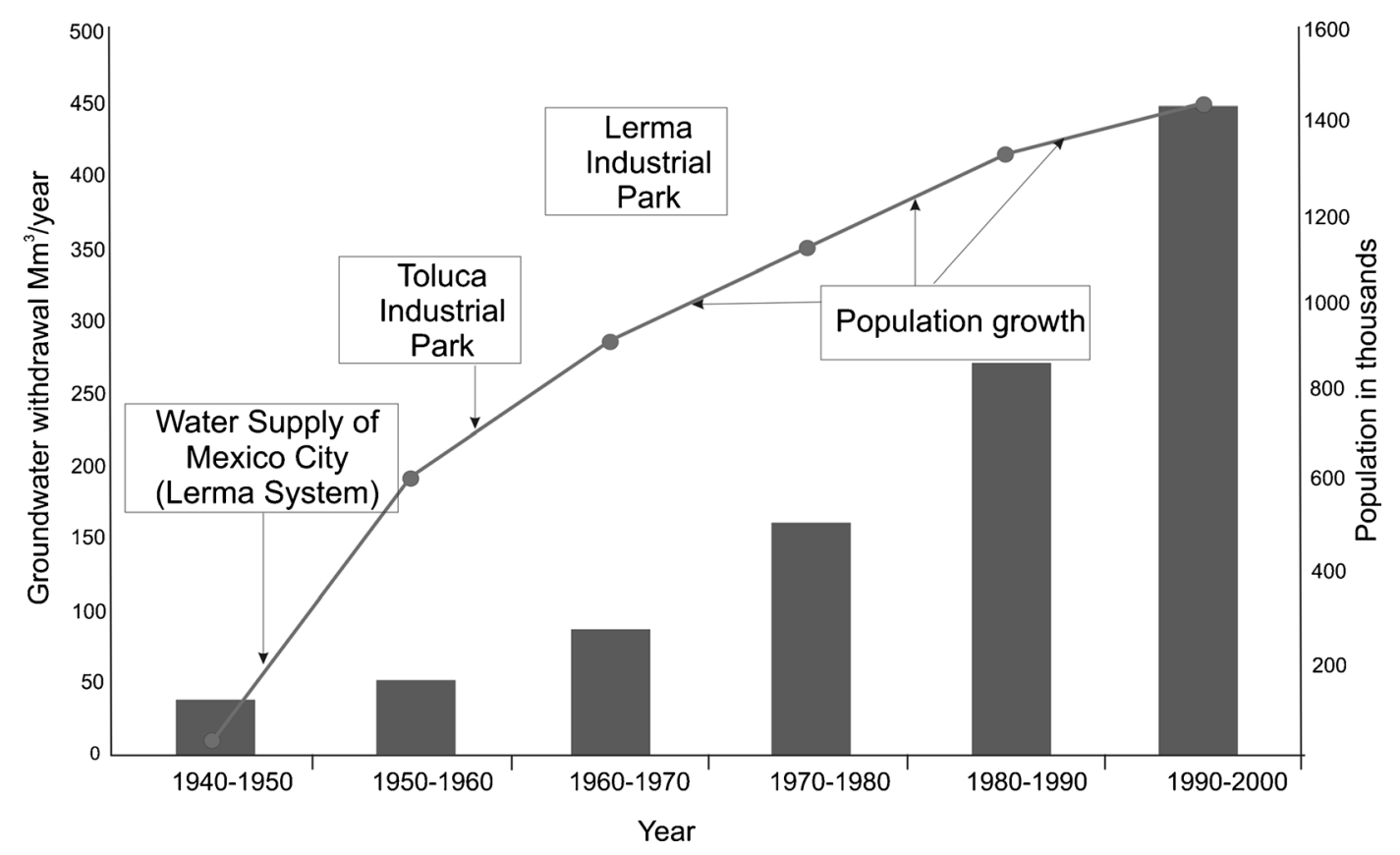

Fig. 3 Relationships between population increase, regional development and groundwater extraction (Mejía et al. 2007b) 


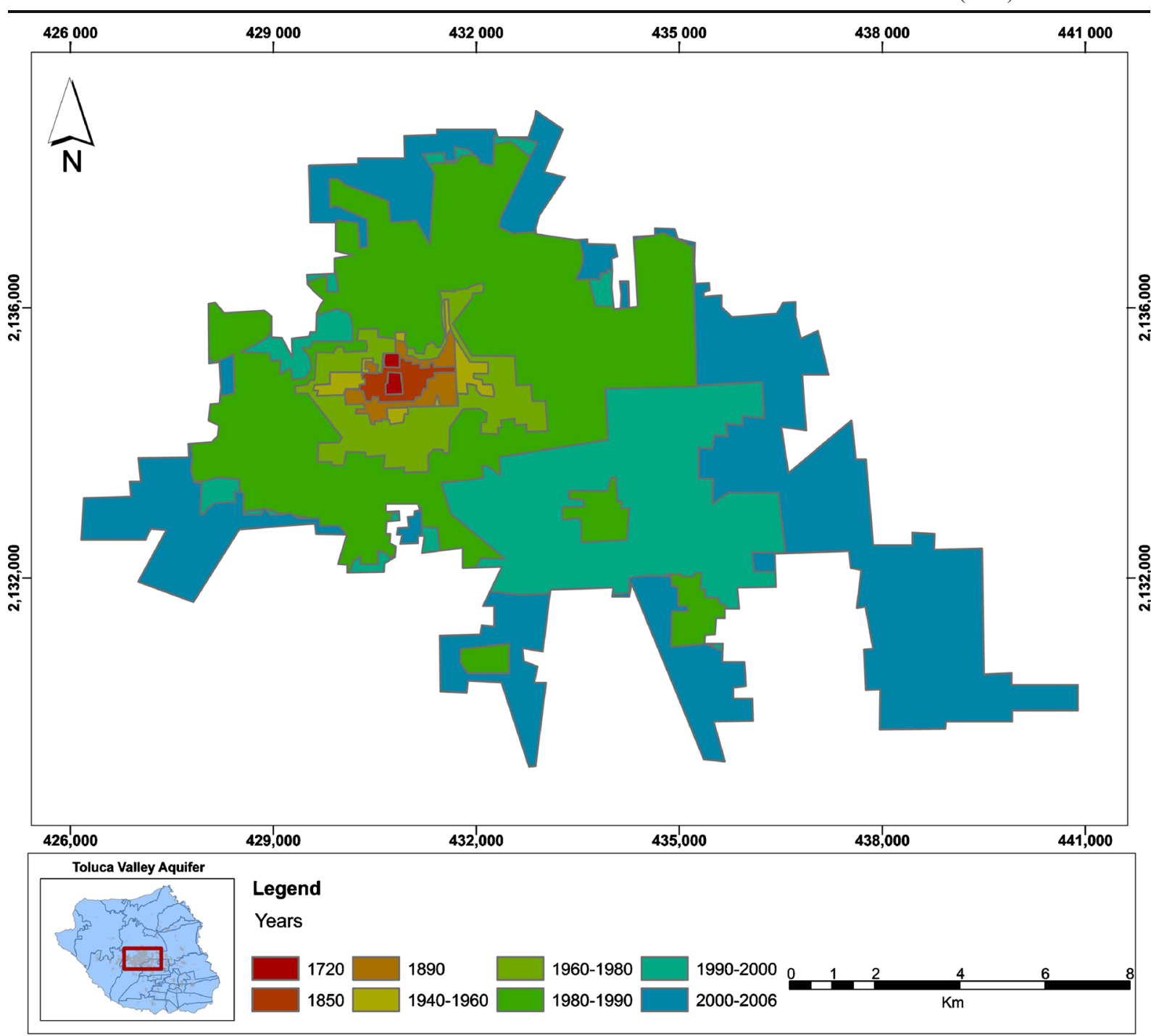

Fig. 4 Growth of the cities of Toluca and Metepec over a 286-year period

Table 1 Number of extraction wells, uses, and pumping rates in the study area (IMTA-CONAGUA 2009)

\begin{tabular}{llc}
\hline & $\begin{array}{l}\text { Number of } \\
\text { wells }\end{array}$ & $\begin{array}{l}\text { Groundwater withdrawal } \\
\left(\mathrm{Mm}^{3} / \text { year }\right)\end{array}$ \\
\hline Agriculture & 3 & 0.11 \\
Industry & 71 & 73.50 \\
Urban supply & 119 & 58.65 \\
Services & 14 & 1.85 \\
Livestock & 1 & 0.01 \\
Otros & 2 & 0.12 \\
Total & 210 & 134.24 \\
\hline
\end{tabular}

groundwater flow systems, with corresponding differences in water level, within the heterogeneous aquifer system.

Figure 7 shows groundwater levels declining over time, with a very evident decrease beginning in the 1980 s, due to intensive extraction from the aquifer in order to meet public and industrial demand (Figs. 3 and 5).

In multilevel monitoring well PL-140 (Fig. 7a), groundwater levels can be seen to have declined over $30 \mathrm{~m}$ during the period 1968-2010, at an average rate of $0.8 \mathrm{~m} /$ year. The same effect can be seen at all monitoring well depths, including the shallowest level of $35 \mathrm{~m}$.

Figure $7 \mathrm{~b}$ shows the evolution of levels in multilevel monitoring well PL-158, where decline over the study 


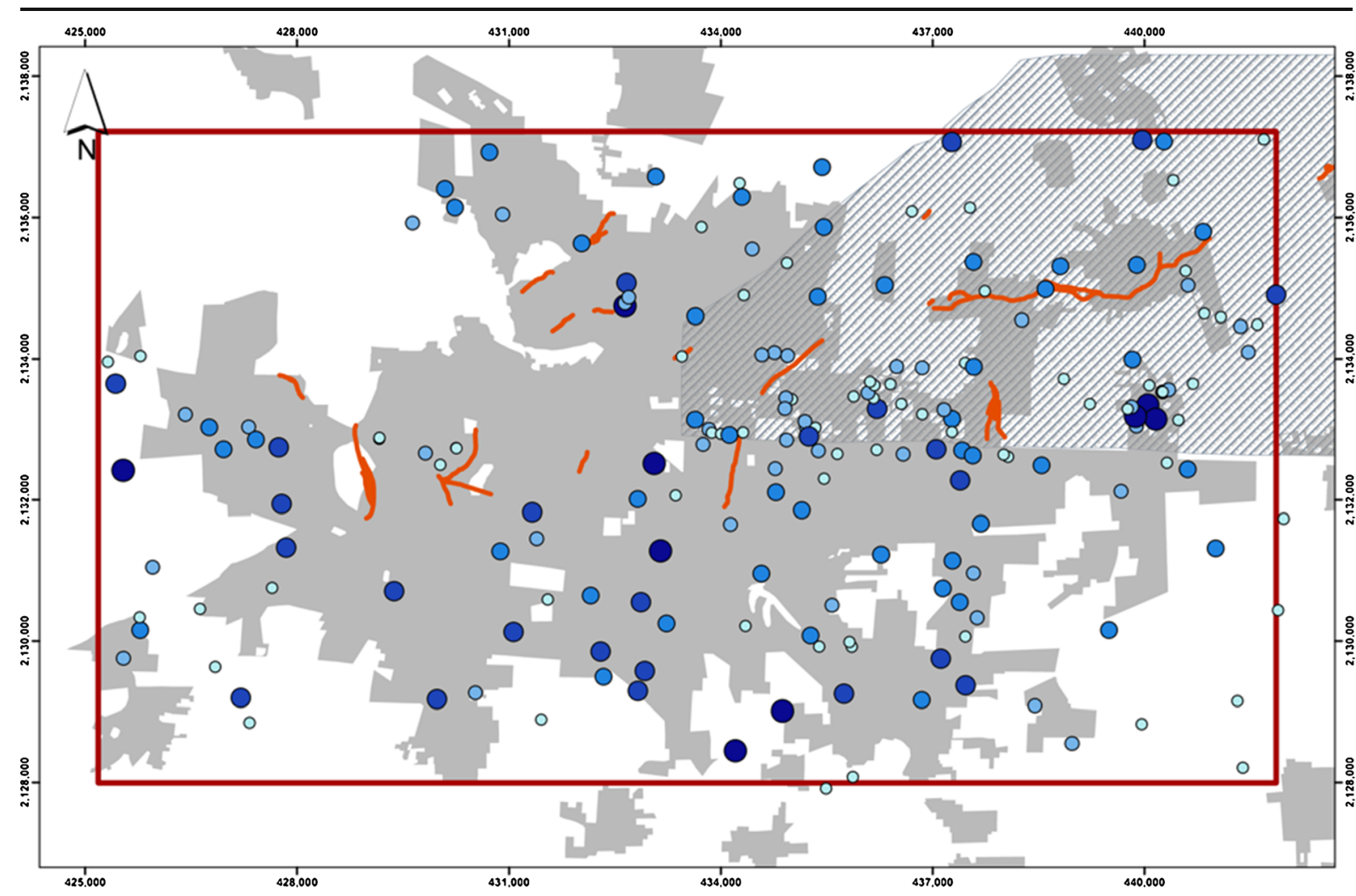

\section{Legend}

$\square$ Study area

\section{Pumping rates $\mathrm{Mm}^{3} /$ year}

Metropolitan zone of the City of Toluca

Z7. Industrial area

- Ground fissures

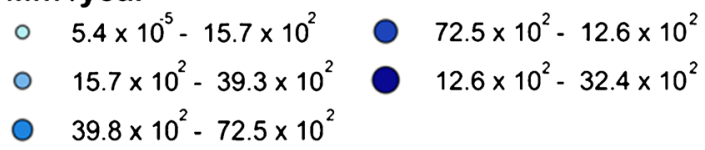

- $39.8 \times 10^{2}-72.5 \times 10^{2}$

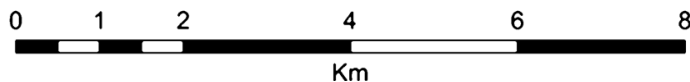

Fig. 5 Spatial distribution of pumping rates (cubic megameter per year) in the study area and ground fissures

period is found to be minimal in piezometers installed at depths of between 26 and $72 \mathrm{~m}$, especially in the shallowest piezometer. In the piezometer at a depth of $112 \mathrm{~m}$, a greater decline of roughly $37 \mathrm{~m}$ is observed, representing a drawdown rate of $0.9 \mathrm{~m} /$ year. At a depth of $135 \mathrm{~m}$, evolution of the water level indicates that, at the beginning of the study period, the groundwater level was higher than that corresponding to the probe installed at a depth of $112 \mathrm{~m}$, which would suggest a "charge" level, a condition that ceases to exist in 1978, after which a sleep decline begins and lasts through 1990, at a rate of $2.55 \mathrm{~m} /$ year (data are not available for previous years). In the deepest piezometer $(150 \mathrm{~m})$, a continuous decline is found between 1968 and 1985, subsequently followed by recovery and then stabilization. This stabilization may be due to the fact that, in 1985, some of the wells located in the City of Toluca were closed as a precautionary measure, due to the appearance of ground fissures.

In multilevel monitoring well PL-201 (Fig. 7c), groundwater levels corresponding to piezometers installed at depths of 66 and $79 \mathrm{~m}$ show a continuous decline of over $40 \mathrm{~m}$ during the 1968-2010 period ( $1 \mathrm{~m} /$ year). On the other hand, recordings from the shallowest piezometers (depths of 36, 23, and $12 \mathrm{~m}$ ) indicate uniform behavior with minimal decline. Nevertheless, beginning in 1985, there is evolution that can be defined as a recovery process, with levels continuing to decline but at a slower rate, and stabilization is even observed in the last decade. It is important to note that this multilevel 
Fig. 6 Lithological columns of multilevel monitoring wells
PL 140

PL 158

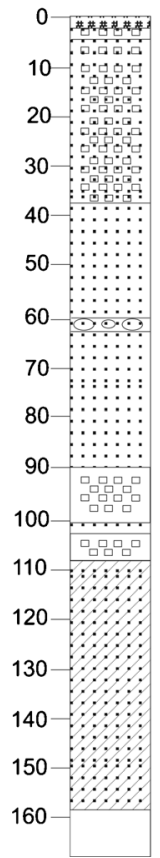

PL 201

\section{PL 205}

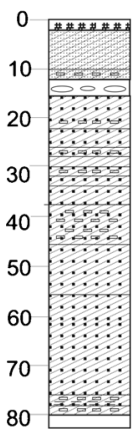

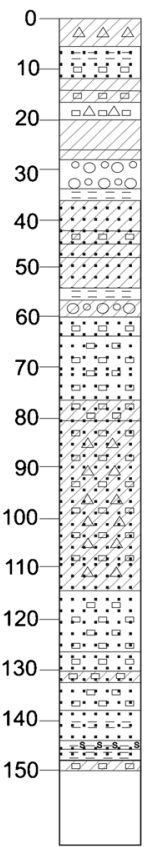

\section{LEGEND}

$\because::::$ SAND

WINA CLAY

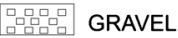

EEE SLT

OOO CONGLOMERATE

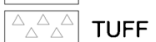

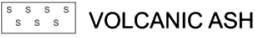

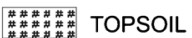

a)

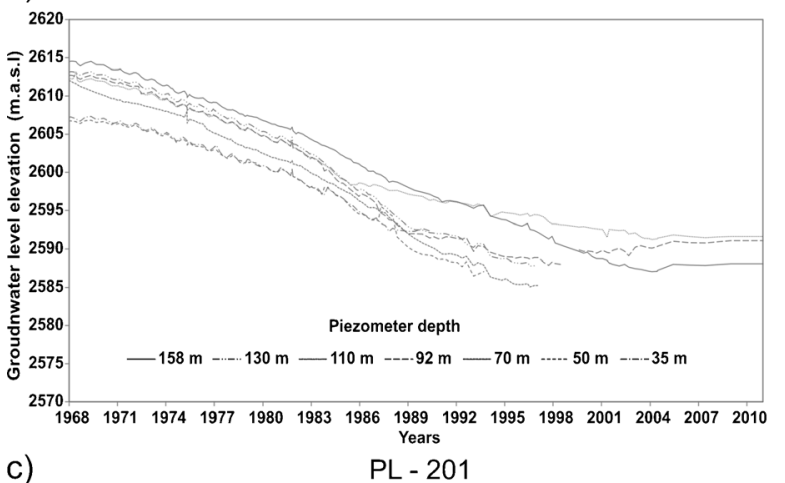

C)

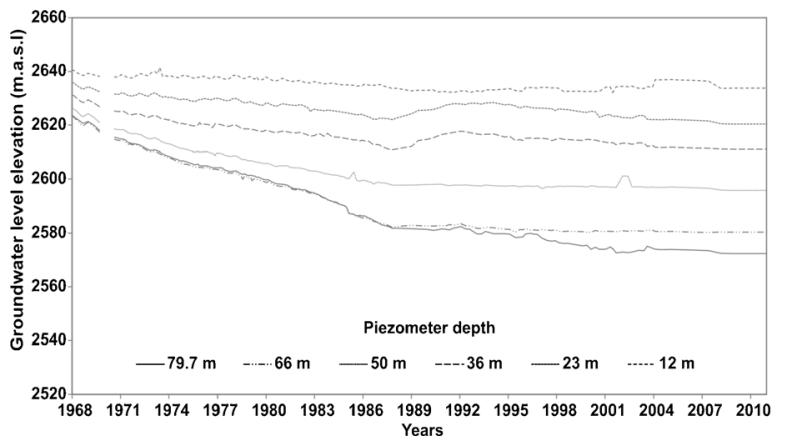

b)

$P L-158$

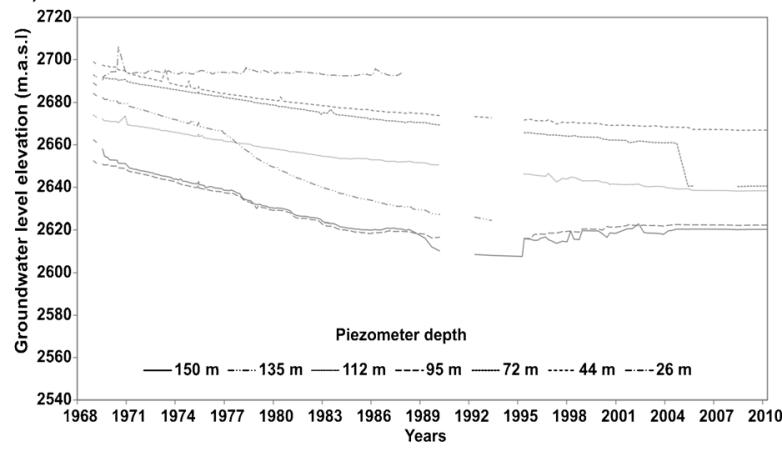

d)

$\mathrm{PL}-205$

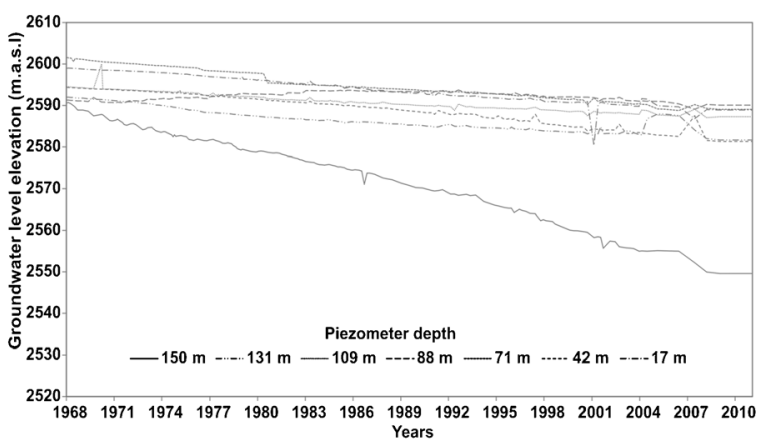

Fig. 7 Temporal evolution of groundwater level elevation for multilevel monitoring wells distributed in the MZCT (Metropolitan Zone of the City of Toluca): a PL-140, b PL-158, c PL-201, and d PL-205 
monitoring well is located in the center of the City of Toluca and may also reflect the suspension of pumping activities at some wells, as mentioned previously.

In the case of the Pl-205 multilevel monitoring well (Fig. 7d), a declining water level trend can be seen at the level of the deepest piezometer $(150 \mathrm{~m})$, with a rate of $1.1 \mathrm{~m} /$ year. The values for levels in the shallowest piezometers show uniform behavior, with no significant changes over the study period.

In summary, the greatest declines are found in the deepest piezometers $(>90 \mathrm{~m})$, with an average of more than $1 \mathrm{~m} /$ year. In addition, uniform behavior can be identified in levels registered at the shallowest piezometers, characterized by minimal decline in levels when compared with the remaining piezometers. The decline in the deepest piezometers can be attributed to the fact that most extraction wells have been drilled to depths of more than $100 \mathrm{~m}$ (IMTA-CONAGUA 2009).

Another contributing factor to temporal evolution in groundwater levels may be associated with reduced recharge volume, as a result of an increase in urban impervious areas. On the other hand, there could be recharge due to reduced evapotranspiration and leaks from drinking water and wastewater mains, as well as infiltration from irrigation of such recreational areas as parks and sports grounds (Lerner 2002; Naik et al. 2008; VázquezSuñé et al. 2005, 2010; Healy 2010; Foster et al. 2011). In the Mexican case, estimated leaks from drinking water mains vary between 30 and $60 \%$ (Jiménez et al. 2010); in Toluca in particular, the estimate is $30 \%$ (Fonseca et al. 2013). No information is available on leaks from the combined wastewater-stormwater runoff mains, but similar percentages are reasonable estimates.

In the case under study, recharge gain and loss factors appear to be in balance. This is reflected in the shallowest piezometric measurements, which show little net decrease when compared with deep piezometers. A particular example is PL-201 (Fig. 7c), located in the center of the urban area (Fig. 1), which seems to be unaffected by changes.

One should bear in mind that deep recharge directly from the surface (or the unsaturated zone in the case of leaks from water and sewage mains) is very limited due to the presence of impermeable layers and aquitards, as mentioned in the description of the study area.

PL-140 is a particular case showing a drop in groundwater level in all piezometers. This can be explained, on the one hand, by the fact that this multipiezometer is located at the edge of the urban area and, as a result, could still be unaffected by urbanization. On the other hand, the fairly uniform sand and gravel lithology found at this location (Fig. 6) may elicit a simultaneous response to pumping.

Figure 7 also shows how vertical hydraulic gradients have evolved. At the beginning of the study period, they were not very significant, as indicated by small differences in the elevation of levels at different depths. As pumping became more intense and its effects more notable (decline in groundwater level, especially at the greatest depths), the vertical gradient began to increase, which may have led to contaminants entering from the soil surface (Rudolph et al. 2005).

\section{Spatial evolution of groundwater level}

As can be seen in the temporal evolution of groundwater levels, significant variations exist in the behavior of these levels, mainly between 1970 and 2010, the period that was studied in order to spatially evaluate these variations (Fig. 8). The map for 1970 (Fig. 8a) shows how groundwater levels range from 2,750 masl in the extreme SW region of the study zone to 2,570 masl in the extreme NE. The hydraulic gradient shows a high value of $1 \%$ in the extreme SW, which decreases in the direction of groundwater flow (SW-NE) to a value of $0.3 \%$ in the extreme NE.

For the year of 1980, the groundwater level configuration does not show any significant change (Fig. 8b). Nevertheless, beginning in the 1990s (Fig. 8c), this configuration undergoes expressive modification, with flow from SW to N and groundwater level values between 2,730 and 2,570 masl, respectively. In addition, during previous decades, groundwater levels showed no variation in the extreme SW, but did undergo changes in their configuration, primarily in the center of the City of Toluca.

These changes continued until the year 2000 (Fig. 8d). Comparing this year with 1970, groundwater level isolines define hydraulic gradients with values of $0.3 \%$ and groundwater levels decline from 2,630 to 2,560 masl. Lastly, comparing the year 2010 with 1970 (Fig. 8a, e), the groundwater level in the extreme NE declined from 2,570 masl in 1970 to 2,550 masl in 2010 , indicating a $20-\mathrm{m}$ reduction in groundwater level in this NE area.

This change in groundwater level configuration is also reflected in flow direction. In 1979, groundwater flowed from SW to NE, whereas in 2010 flow converged onto the industrial zone. 


\section{a) 1970}

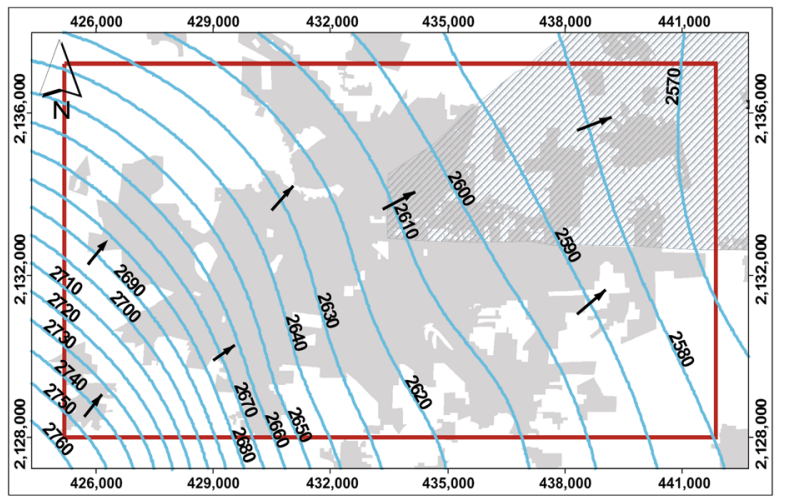

\section{c) 1990}

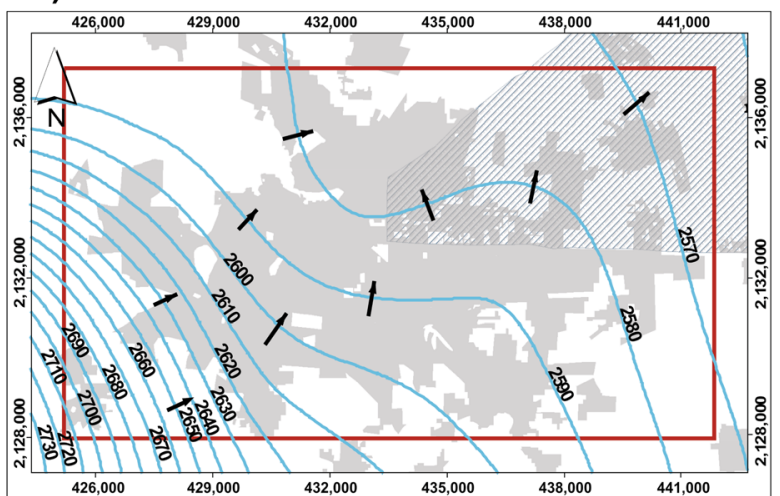

b) 1980

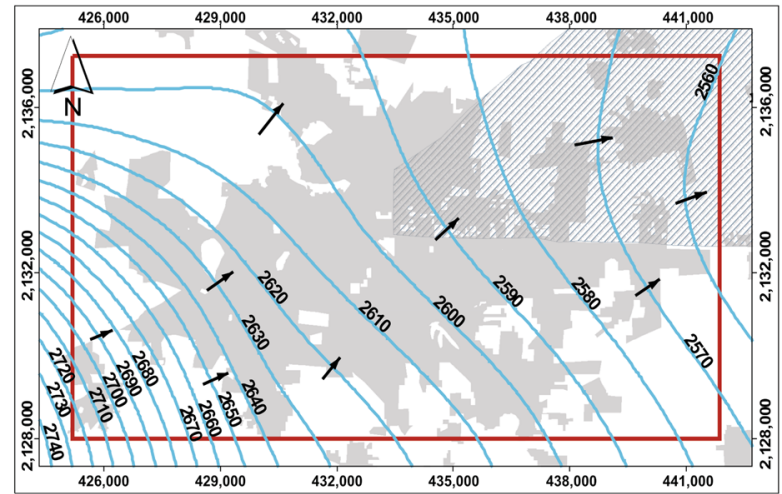

d) $\mathbf{2 0 0 0}$

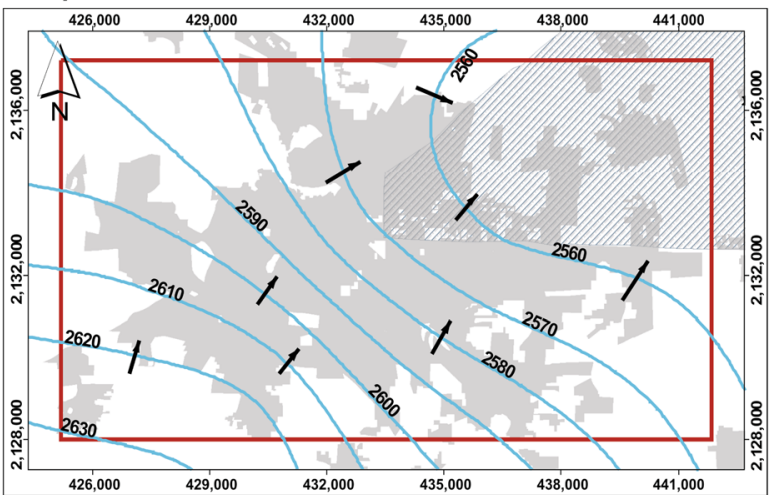

\section{e) 2010}

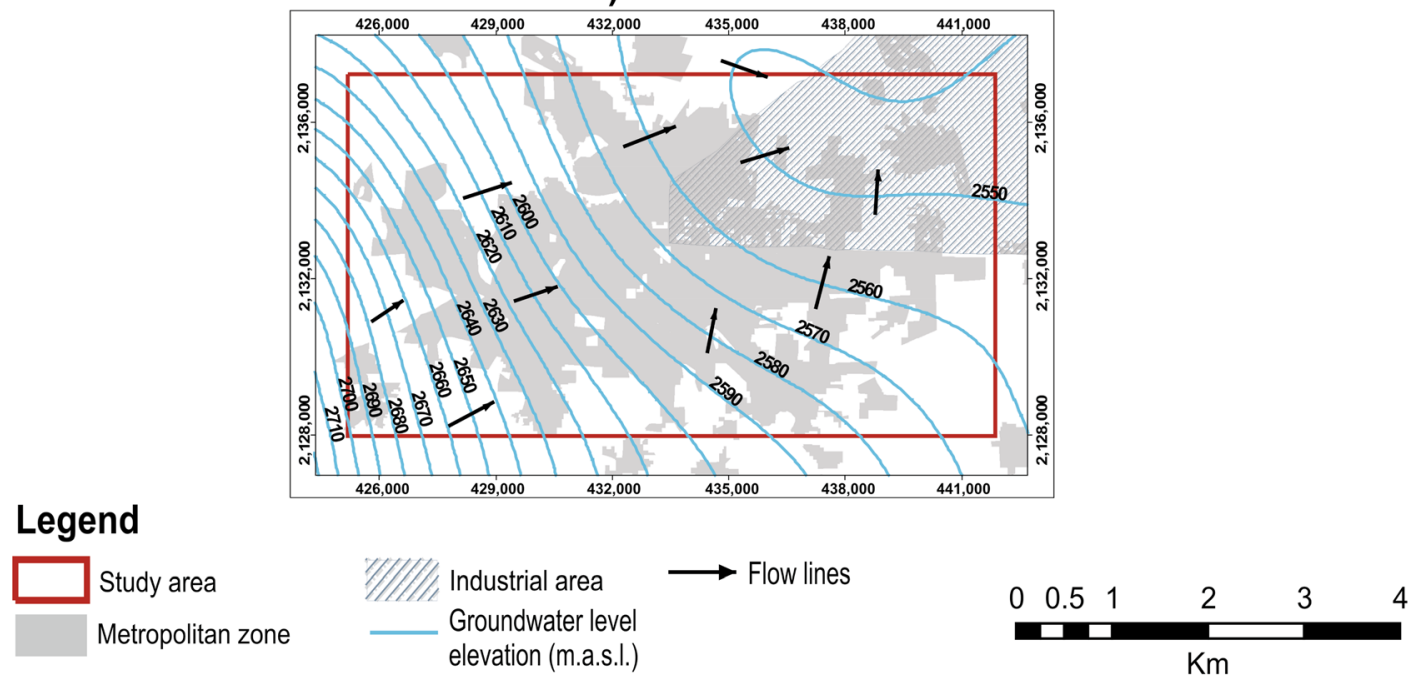

Fig. 8 Groundwater level contour map (meters above sea level) for years a 1970, b 1980, c 1990, d 2000, and e 2010 and flow paths

The map of drawdown isopleths for the period 19702010 (Fig. 9) shows the greatest accumulated declines (over $40 \mathrm{~m}$ ) occurring in the central portion of the Toluca Valley aquifer, defining a drawdown cone that encompasses most of the urban zone and extends towards the northeast (industrial zone).

It is worth mentioning that, in 1970, the deepest water level was determined to be $50 \mathrm{~m}$ in the southern 


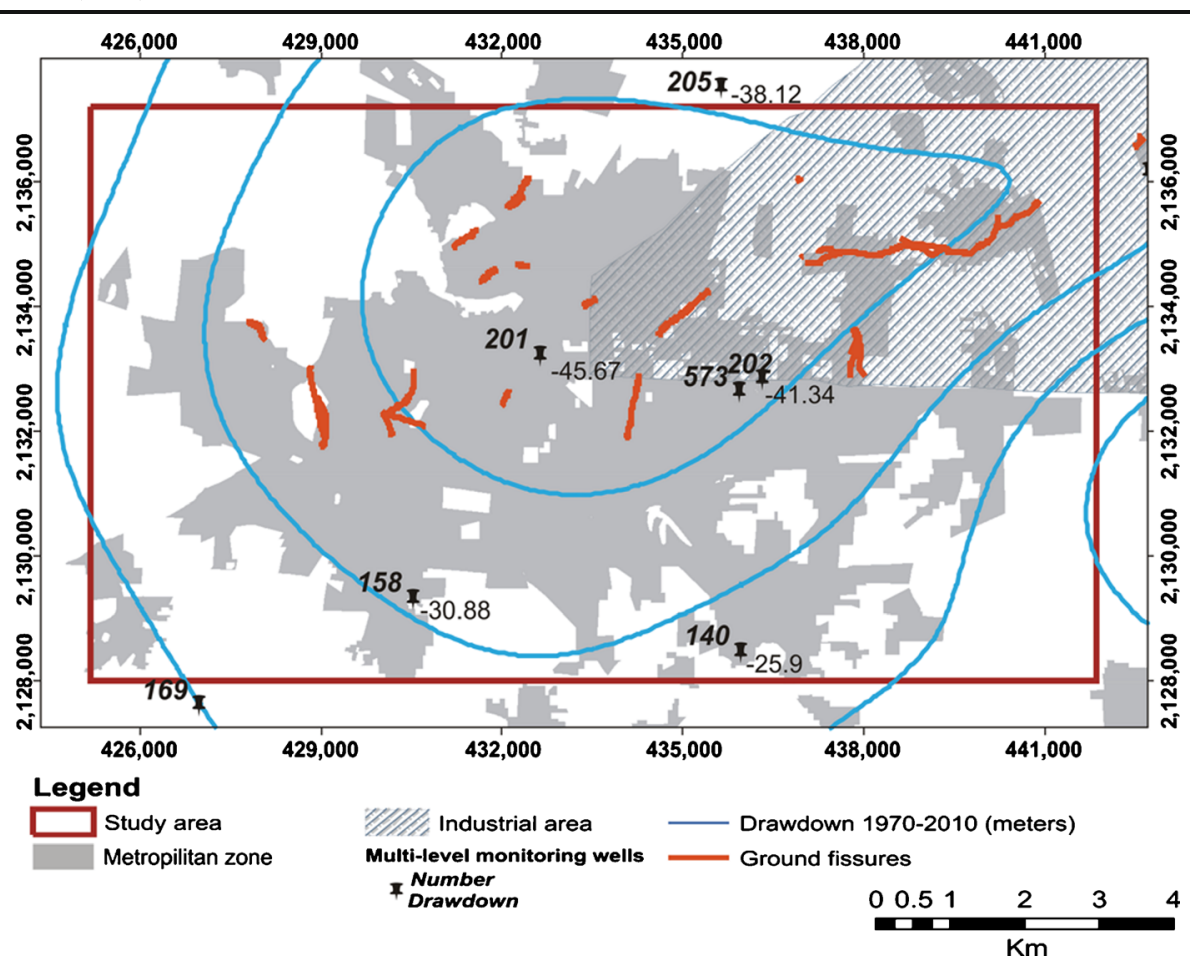

Fig. 9 Map of drawdown isopleths in meters between 1970 and 2010

portion of the City of Toluca, while in the remainder of the study area levels were between 10 and $30 \mathrm{~m}$ deep. However, in the year 2010, the groundwater level depth was over $85 \mathrm{~m}$ in the southern portion of the city and ranged between 20 and $60 \mathrm{~m}$ in the remainder of the study area.

\section{Ground fissures}

Several fissures have been identified in the urban and industrial zone (Fig. 9) that appear to be related to both well density and extraction volumes (Fig. 5). It is important to mention that the most extensive fissure, San Pedro Totoltepec (4.5 km length), is located in the sector identified as industrial. The greatest fissure effects are observed in residential housing areas, where fissures effecting channels filled with wastewater and sewage networks may cause groundwater contamination. In addition, it is important to mention that water extraction wells exist near the fissures, and therefore, they may be at risk of contamination. Such risk could be detected by the presence of anomalous concentrations of certain elements or chemical compounds, for example, $\mathrm{Cl}^{-}$, $\mathrm{SO}_{4}{ }^{2-}, \mathrm{B}, \mathrm{F}^{-}, \mathrm{Br}$, EDTA, Zn, and total nitrogen (Naik et al. 2008; Vázquez-Suñé et al. 2010).
Hydrochemical changes

The chemical characteristics of groundwater for 1991, 1998, 2004, and 2010 were spatially represented using Stiff diagrams (Fig. 10), based on data obtained from samples collected over the years. This spatial representation shows that groundwater in the study area has similar characteristics, and its $\mathrm{Mg}-\mathrm{Na}-\mathrm{HCO}_{3}$ composition does not change drastically over time. No sectors are found to have any specific different characteristics.

The temporal evolution of $\mathrm{NO}_{3}{ }^{-}, \mathrm{Cl}-$, and $\mathrm{SO}_{4}{ }^{2-}$ concentrations was evaluated in detail, making it possible to identify anthropogenic contamination related to wastewater discharge as well as sewage main leaks (Bathrellos et al. 2007; Leung et al. 2004; Wolf et al. 2006; Corniello et al. 2007). This is found particularly in the case of the Bomberos and SEDAGRO wells (Fig. 11).

The SEDAGRO well is located in the southern sector of the study zone and has information available for 2004, 2005, 2007, 2008, 2009, and 2010. Figure 11a shows how concentrations of $\mathrm{Cl}^{-}, \mathrm{NO}_{3}{ }^{-}$, and $\mathrm{SO}_{4}{ }^{2-}$ have increased over the years. In the case of the Bomberos well, located within the urban footprint of the City of Toluca, a certain continuity of information is available, with data for 1999, 2004, and 2005, as well as 


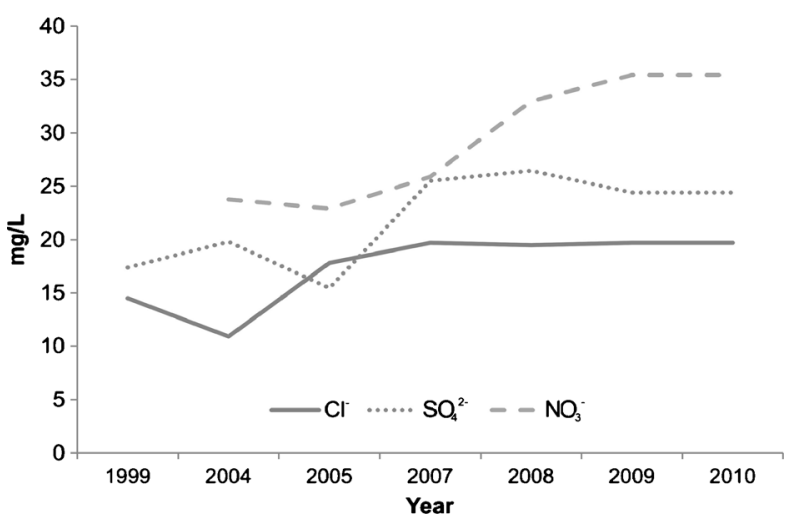

a) SEDAGRO

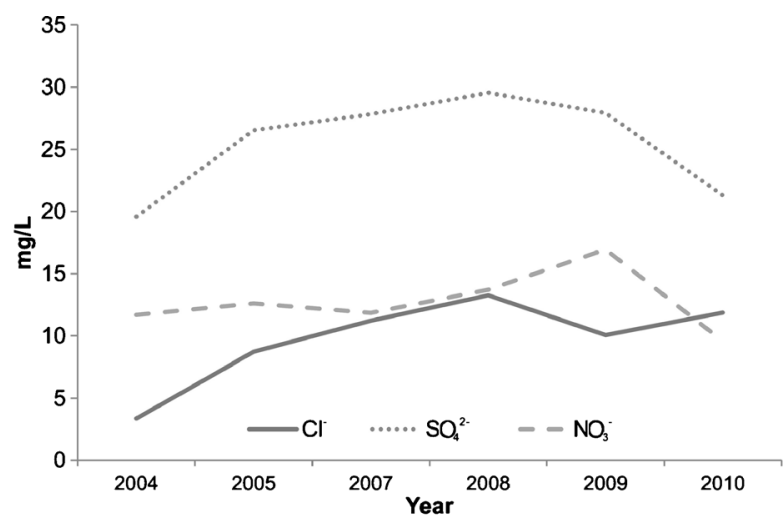

b) Bomberos

Fig. 10 Temporal evolution of groundwater chemistry at selected wells: a SEDAGRO and b Bomberos

the period from 2007 to 2010 (Fig. 11b). Similar to the SEDAGRO well, a tendency is seen for concentrations of these ions to increase, especially $\mathrm{SO}_{4}{ }^{2-}$.

Figure 12 shows isoconcentration maps for nitrates for the period 1991-2010. In 1991 (Fig. 12a), the highest concentrations of nitrates $(15 \mathrm{mg} / \mathrm{L})$ were detected in the SE and NE sectors, whereas in the remainder of the zone, concentrations were less than $5 \mathrm{mg} / \mathrm{L}$. In 1998 (Fig. 12b), the highest $\mathrm{NO}_{3}{ }^{-}$concentrations were found in the northern portion of the City of Toluca, with values of $25 \mathrm{mg} / \mathrm{L}$, whereas lower concentrations were observed in the central part of the city, with values of $5 \mathrm{mg} / \mathrm{L}$. In the SE and the NE portions, concentrations between 5 and $15 \mathrm{mg} / \mathrm{L}$ were present. In 2004 (Fig. 12c), the highest concentrations of $\mathrm{NO}_{3}{ }^{-}$were identified in the NE sector of the study zone, with values between 10 and $15 \mathrm{mg} / \mathrm{L}$. In 2010 (Fig. 12d), the highest concentrations were located in the central area, with maximum values of $30 \mathrm{mg} / \mathrm{L}$, whereas concentrations were less than $5 \mathrm{mg} / \mathrm{L}$ in the remainder of the zone.

It is important to emphasize that the zone with the highest concentrations of $\mathrm{NO}_{3}{ }^{-}$corresponds to the urban area, and therefore, based on an initial evaluation, it can be inferred that these values are due to the influence of domestic sewage discharge. This is consistent with such studies as Jin et al. (2003), Corniello et al. (2007), and Wolf et al. (2006), indicating serious problems related to leaks in sewage mains, which could contribute to a certain amount of nutrients and salts, particularly nitrate.

Assessment of chemical characteristics: 2010 sampling survey

Table 2 shows the results of descriptive statistics concerning data from physical-chemical analysis of samples collected during 2010. The $\mathrm{pH}$ of groundwater was neutral to slightly alkaline (6.82-7.89; mean of 7.40). Electrical conductivity and TDS values ranged from 202 to $584 \mu \mathrm{S} / \mathrm{cm}$ (mean of $321 \mu \mathrm{S} / \mathrm{cm}$ ) and from 110 to $328 \mathrm{mg} / \mathrm{L}$ (mean of $183 \mathrm{mg} / \mathrm{L}$ ), respectively, and therefore groundwater can be considered to be of low salinity. Based on the mean values of ions present in the water, the order of abundance of majority cations was $\mathrm{Na}^{+}>\mathrm{Ca}^{2+}>\mathrm{Mg}^{2+}>\mathrm{K}^{+}$, and in the case of anions, it was $\mathrm{HCO}_{3}{ }^{-}>\mathrm{SO}_{4}{ }^{2-}>\mathrm{Cl}^{-}>\mathrm{NO}_{3}{ }^{-}$. The presence of $\mathrm{Si}$ is particularly noteworthy, with a mean concentration of $46.06 \mathrm{mg} / \mathrm{L}$ and a maximum concentration of $51.90 \mathrm{mg} / \mathrm{L}$. The high degree of dispersion of some chemical parameters, for example, $\mathrm{SO}_{4}{ }^{2-}, \mathrm{NO}_{3}{ }^{-}$, and $\mathrm{K}^{+}$, expressed as a variation coefficient, indicates variations in the hydrochemistry of groundwater.

Differences in the concentrations of majority ions can be explained by the lithology of the aquifer, as well as differences in water residence time, since longer residence contributes to the enrichment of $\mathrm{Na}^{+}$, for example (Esteller et al. 2012). It is also important to consider the incidence of anthropic factors related to urban land use (Jeong 2001; Naik et al. 2008). With respect to compliance with quality standards established for water destined for human consumption and use, only $\mathrm{NO}_{3}{ }^{-}$and Fe exceed the limits established by Mexican legislation.

The Piper diagram (Fig. 13) shows groundwater as sodium-magnesium bicarbonate water, with a low to medium sulfate and chloride content, although magnesium-sodium and magnesium-calcium water types were also identified. This diagram also shows the existence of three clusters: GI, GII, and GIII.

The GI cluster corresponds to wells with a higher sulfate content and includes samples 3, 8, 10, 28, and 34 


\section{a) 1991}

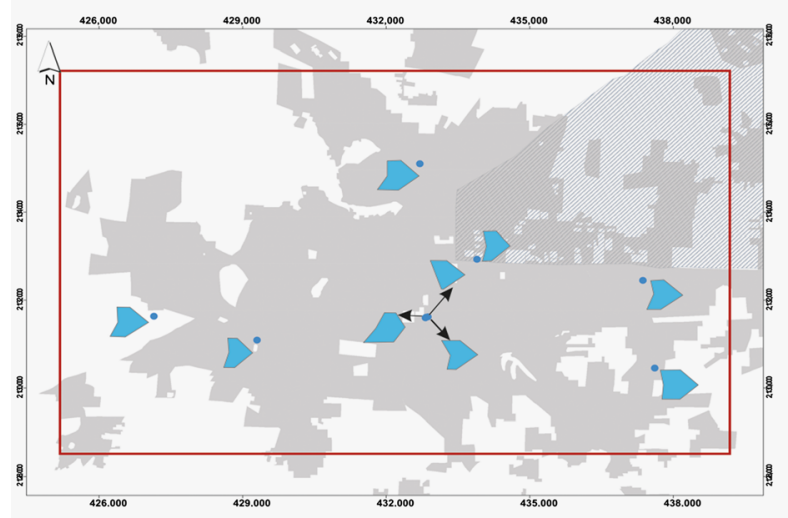

c) 2004

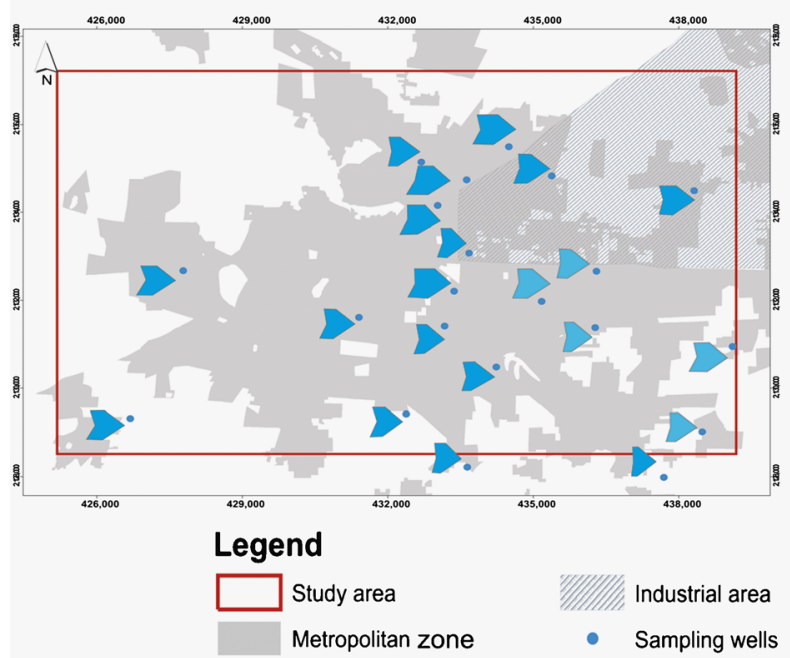

b) 1998

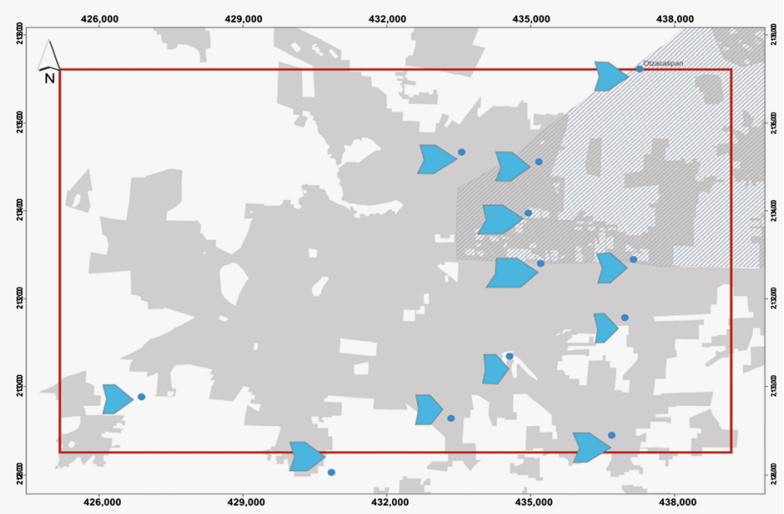

d) 2010
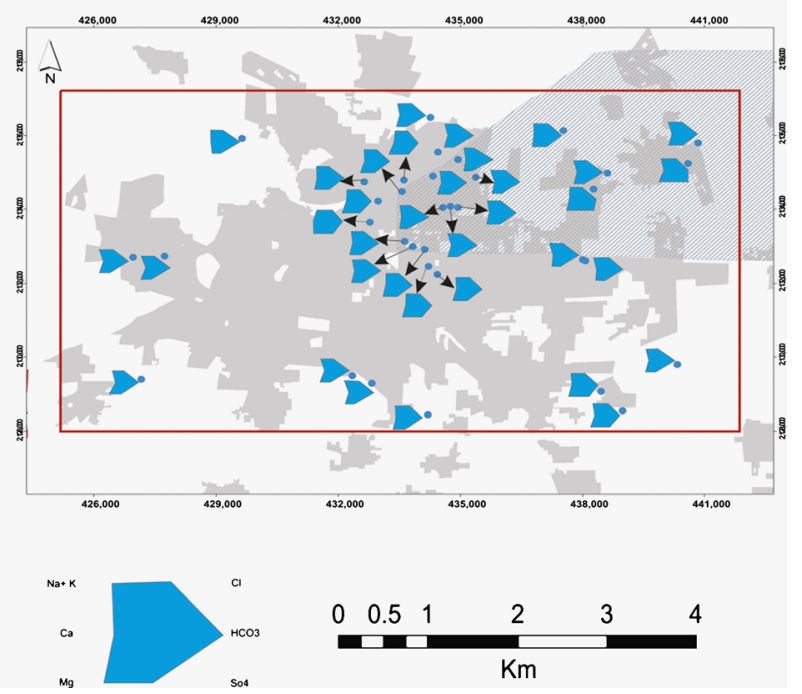

Fig. 11 Stiff diagrams for selected wells in the MZCT: a 1991, b 1998, c 2004, and d 2010

and samples 18 and 20, which are identified as the San Antonio Abad and Santa María Totoltepec wells, respectively (Fig. 1), located in the vicinity of the San Pedro Totoltepec fissure. The GII group includes samples with a lower sulfate content. Some of these samples $(2,4,5,26$, and 31) are also located near fissures (Fig. 1), although such samples as 9, 19, and 22 do not appear to be related to the presence of fractures. It is also important to consider the possibility that not all fractures in the aquifer have been mapped.

Another aspect of note is that the samples included in these two groups also have high nitrate values $(>5 \mathrm{mg} / \mathrm{L})$, although they do not exceed $45 \mathrm{mg} / \mathrm{L}$, indicating an anthropogenic contaminant input.

The GIII group consists of samples containing less sulfate (and nitrate, although there are some exceptions, for example, samples $6,13,21,33$, and 35), and as a result, this group could represent the aquifer without anthropogenic interference, which is characterized by calcium bicarbonate water.

As already mentioned, the GI cluster is characterized by high concentrations of sulfate, with two points that stand out as being characterized by sulfate-bicarbonate water. These points correspond to the San Antonio Abad (18) and Santa María Totoltepec (20) wells, both of which are located less than $500 \mathrm{~m}$ from the San Pedro Totoltepec fissure, in the NE portion of the study zone where land use is primarily industrial.

The San Antonio Abad well is one of the 82 wells operated by the Toluca Water and Sanitation Company. It has a constructed depth of $134 \mathrm{~m}$ and a static water level depth of $38 \mathrm{~m}$. On the other hand, the Santa María Totoltepec well is operated by the local drinking water commission. This well has a constructed depth of 
a) 1991

b) 1998

c) 2004
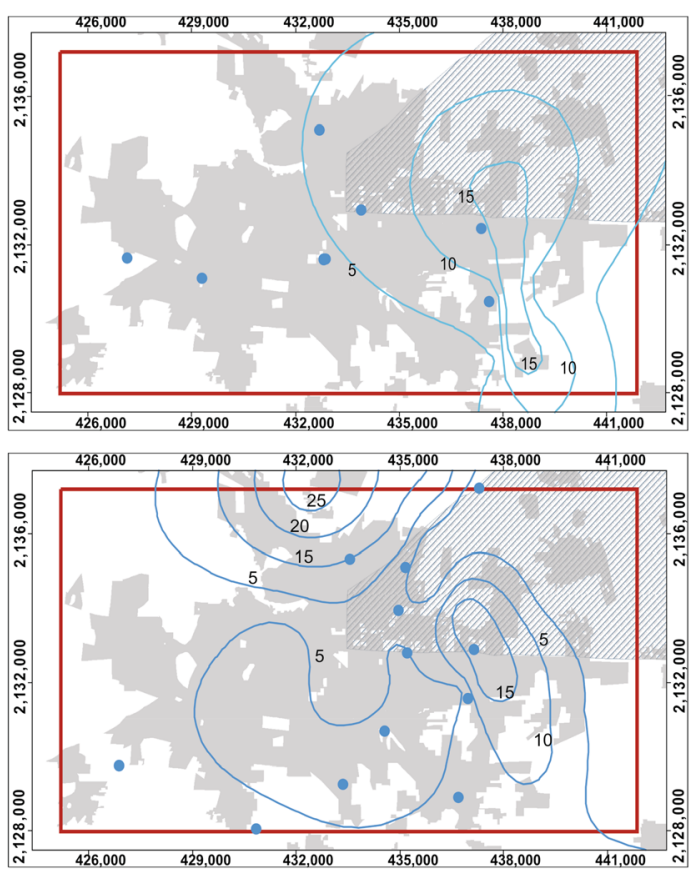

d) 2010
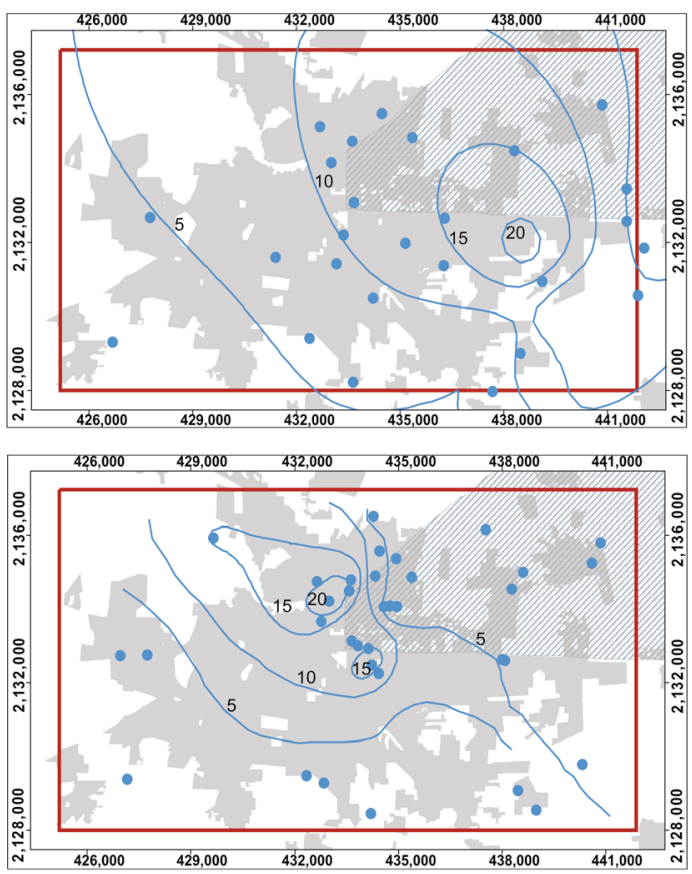

\section{Legend}
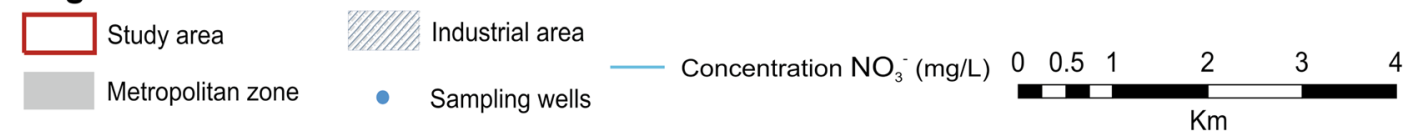

Fig. 12 Spatial distribution of nitrate concentrations in the study zone: a 1991, b 1998, c 2004, and d 2010 (in milligrams per liter)

approximately $267 \mathrm{~m}$ and a static water level of $42 \mathrm{~m}$ below the ground surface.
Table 3 shows the physical-chemical characteristics of water extracted from the Santa María Totoltepec and 
Table 2 Summary of the physical-chemical parameters of groundwater (sampling survey $2010 ; n=35$ )

n.d. not detected

\begin{tabular}{lrrrrll}
\hline Parameters $(\mathrm{mg} / \mathrm{L})$ & \multicolumn{1}{l}{2010} & & & & & \\
\cline { 2 - 7 } & \multicolumn{1}{l}{ Min } & \multicolumn{1}{c}{ Max } & Mean & $\begin{array}{c}\text { Standard } \\
\text { deviation }\end{array}$ & $\begin{array}{l}\text { Variance } \\
\text { coefficient }\end{array}$ & $\begin{array}{l}\text { Mexican drinking } \\
\text { water standards }\end{array}$ \\
\hline $\mathrm{pH}$ & 6.82 & 7.89 & 7.40 & 7.59 & 14 & $6.5-8.5$ \\
$T\left({ }^{\circ} \mathrm{C}\right)$ & 15.1 & 25.0 & 17.94 & 2.12 & 40 & \\
$\mathrm{EC}(\mu \mathrm{S} / \mathrm{cm})$ & 202.50 & 584.40 & 321.01 & 89.25 & 65 & \\
$\mathrm{Ca}^{2+}$ & 11.56 & 52.05 & 19.18 & 7.77 & 78 & \\
$\mathrm{~K}^{+}$ & 1.60 & 19.95 & 3.67 & 2.99 & 92 & \\
$\mathrm{Mg}^{2+}$ & 8.08 & 31.25 & 15.91 & 5.65 & 74 & \\
$\mathrm{Fe}^{2+}$ & 0.06 & 1.71 & 0.34 & 0.42 & 96 & 0.30 \\
$\mathrm{Mn}^{+}$ & $<0.10$ & 0.17 & $<0.10$ & - & - & 0.15 \\
$\mathrm{Na}^{+}$ & 17.46 & 48.65 & 24.03 & 6.36 & 64 & 200 \\
$\mathrm{SO}_{4}{ }^{2-}$ & 7.37 & 117.51 & 33.79 & 28.66 & 94 & 400 \\
$\mathrm{Cl}^{-}$ & 9.22 & 27.28 & 15.74 & 4.25 & 66 & 250 \\
$\mathrm{NO}_{3}{ }^{-}$ & 0.22 & 46.89 & 8.17 & 10.33 & 100 & 44.3 \\
$\mathrm{HCO}_{3}^{-}$ & 75.64 & 225.00 & 134.50 & 29.66 & 66 & \\
$\mathrm{Si}^{-}$ & 36.00 & 51.90 & 46.06 & 3.87 & 31 & \\
\hline & & & & & & \\
\hline
\end{tabular}

San Antonio Abad wells during the 2010 sampling campaign. The predominant anions seen in this table are bicarbonate and sulfate, whereas the principal cation is sodium; none of the parameters analyzed exceed established drinking water limits. The source of this high sulfate content may be related to several factors,
Fig. 13 Piper diagram of hydrochemical data in the study area: 2010 sampling survey

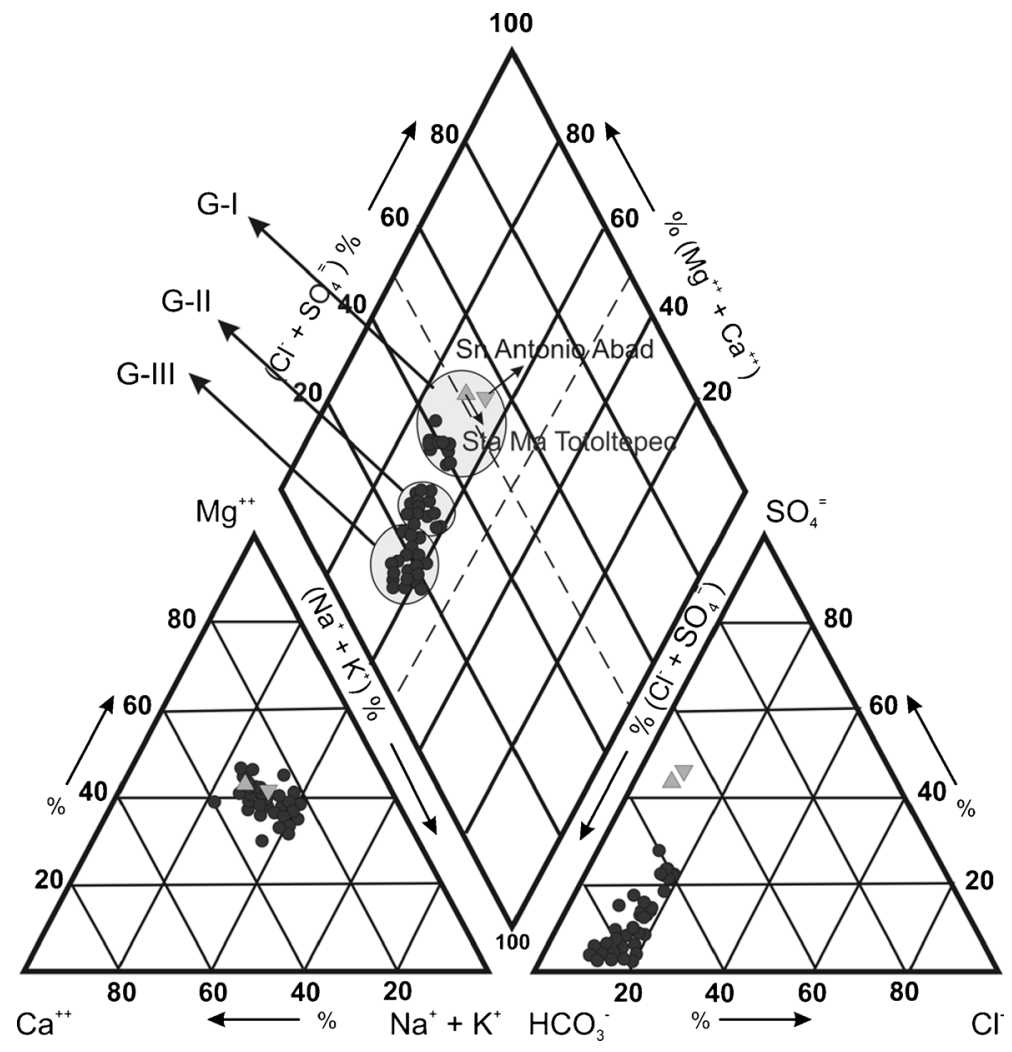


Table 3 Physical-chemical parameters of two groundwater samples located near fissures (sampling survey 2010)

\begin{tabular}{lll}
\hline Parameters $(\mathrm{mg} / \mathrm{L})$ & San Antonio Abad & Santa María Totoltepec \\
\hline $\mathrm{pH}$ & 7.54 & 7.46 \\
$T\left({ }^{\circ} \mathrm{C}\right)$ & 18.4 & 17.9 \\
$\mathrm{EC}(\mu \mathrm{S} / \mathrm{cm})$ & 584 & 360 \\
$\mathrm{TDS}$ & 328 & 205 \\
$\mathrm{Ca}^{2+}$ & 35.05 & 23 \\
$\mathrm{Mg}^{2+}$ & 31.25 & 18.07 \\
$\mathrm{Fe}^{+}$ & $<0.10$ & $<0.10$ \\
$\mathrm{Mn}^{+}$ & $<0.10$ & $<0.10$ \\
$\mathrm{Na}^{+}$ & 48.65 & 22.85 \\
$\mathrm{~K}^{+}$ & 3.91 & 3.31 \\
$\mathrm{HCO}_{3}{ }^{-}$ & 150 & 125 \\
$\mathrm{SO}_{4}{ }^{-}$ & 117.51 & 86.01 \\
$\mathrm{Cl}^{-}$ & 16.59 & 11.8 \\
$\mathrm{NO}_{3}{ }^{-}$ & 0.22 & 2.21 \\
$\mathrm{Si}^{-}$ & 50.7 & 47.2 \\
\hline
\end{tabular}

including type of contaminant and geochemistry. The assumption must be made that sulfate concentrations vary around $60 \mathrm{mg} / \mathrm{L}$ in areas where there are no minerals that contain sulfides (pyrite, for example) or sulfates (gypsum, anhydrite) and that in these areas the origin is primarily atmospheric (Hudak and Sanmanee 2003). Given that higher concentrations have been identified in the study area, the existence of anthropogenic sources must be assumed. For example, sulfate concentrations in urban wastewater normally range from 100 to $300 \mathrm{mg} / \mathrm{L}$ (Vázquez-Suñé 2003), the sources of which include urine, feces, washing clothes, and kitchen wastes. High concentrations of sulfates are also detected in industrial wastewater (Hudak and Sanmanee 2003; Choi et al. 2005), and therefore, it can be presumed that this wastewater could contribute to the presence of sulfates in groundwater as a result of infiltration through fissures.

It is important to take into account ("Spatial evolution of groundwater level" section) that there is a certain degree of hydraulic isolation between deep productive levels and shallow aquifer levels due to the existence of an aquitard. Therefore, fissures play an important role in creating preferential flow pathways and permitting contaminant migration from the surface (Bense et al. 2003; Kontogianni et al. 2007). Several examples of investigations exist that have focused on relating fissures to contamination of deep aquifers. For example, the study developed by Borja and Rodríguez (2004) in the Salamanca aquifer, Mexico, demonstrates how electrical conductivity increased as much as threefold in areas with fissures, as well as a rapid transit time of substances through fissures. This access to the aquifer is demonstrated by the presence of vanadium groundwater originating from thermoelectric power plant emissions (Mejía et al. 2007a).

Assessment of contributions by factor analysis

Previous sections have indicated that water chemistry in this sector of the aquifer is the result of natural waterrock interaction and anthropogenic processes principally related to pollutant seepage. To better distinguish the influence on groundwater chemistry of these two sets of processes, factor analysis was used.

Factor analysis indicates that five factors explain nearly $100 \%$ of the total sample variance $(63.52$, $22.35,8.12,5.73$, and $0.27 \%$ with eigenvalues of $7.83,1.70,0.61,0.43$, and 0.02 for factors I, II, III, IV, and $\mathrm{V}$, respectively). Varimax rotation enabled factors I and II to explain $85.87 \%$ of the variance. This high percentage suggests two processes driving groundwater chemistry in the study zone.

Factor I, explaining $63.5 \%$ of the total variance, had a strong positive correlation $(>0.75)$ with $\mathrm{Mg}^{2+}, \mathrm{Ca}^{2+}$, and EC parameters and a moderate correlation $(0.50$ $0.75)$ to $\mathrm{Na}^{+}, \mathrm{K}^{+}, \mathrm{Cl}^{-}, \mathrm{SO}_{4}{ }^{2-}$, and $\mathrm{NO}_{3}{ }^{-}$(Table 4). Factor II, which added $22 \%$ to variance explanation, was

Table 4 Loading for Varimax-rotated factor matrix of two-factor model explaining $85.87 \%$ of the total variance

\begin{tabular}{lrr}
\hline Variable & Factor I & Factor II \\
\hline $\mathrm{EC}$ & 0.93 & 0.40 \\
$T$ & -0.08 & 0.42 \\
$\mathrm{Na}^{+}$ & 0.53 & 0.74 \\
$\mathrm{~K}^{+}$ & 0.62 & -0.29 \\
$\mathrm{Mg}^{2+}$ & 0.84 & 0.46 \\
$\mathrm{Ca}^{2+}$ & 0.97 & 0.19 \\
$\mathrm{Cl}^{-}$ & 0.56 & 0.15 \\
$\mathrm{SO}_{4}{ }^{2-}$ & 0.61 & 0.08 \\
$\mathrm{NO}_{3}{ }^{-}$ & 0.59 & -0.48 \\
$\mathrm{HCO}_{3}{ }^{-}$ & 0.22 & 0.75 \\
$\mathrm{Si}^{2}$ & 0.13 & 0.46 \\
Eigenvalue & 4.83 & 1.70 \\
Variance (\%) & 63.52 & 22.35 \\
\hline
\end{tabular}


Fig. 14 Factor score cross plot showing position of variables with respect to factor I and factor II

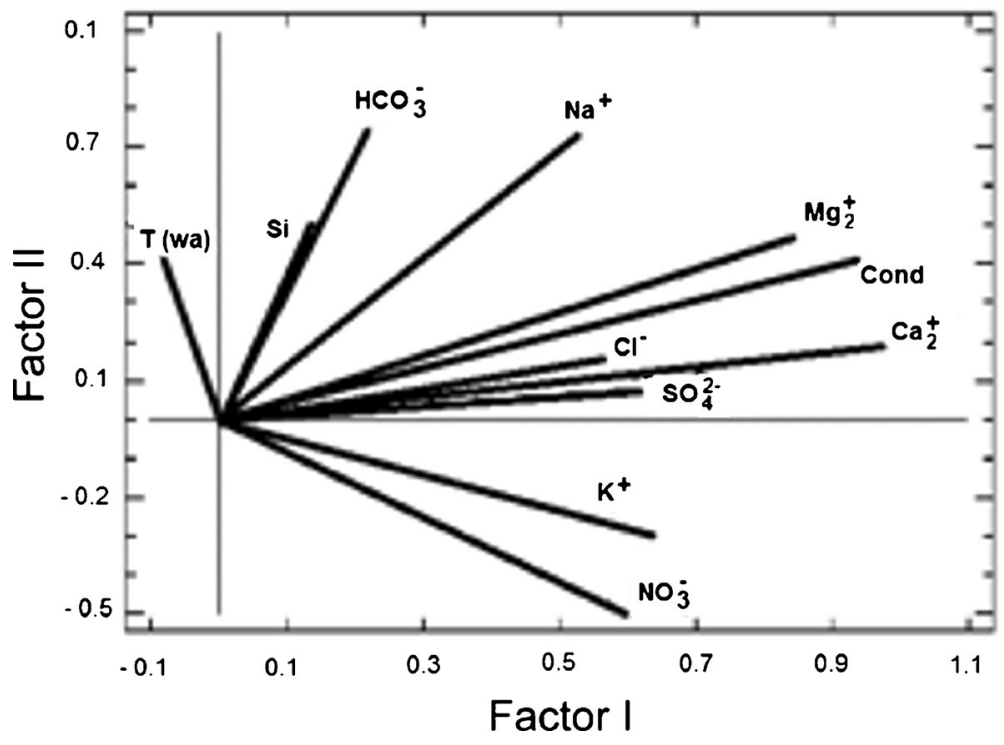

strongly and positively correlated with $\mathrm{Na}^{+}$and $\mathrm{HCO}_{2}{ }^{-}$, moderately with $\mathrm{Si}$ and $\mathrm{Mg}^{2+}$, and to a lesser degree with temperature (Table 4). Factor I likely represented the basic process of groundwater mineralization, in which certain types of contaminants can be presentrelated to $\mathrm{SO}_{4}{ }^{2-}$ and $\mathrm{Cl}^{-}$as well as $\mathrm{NO}_{3}{ }^{-}$and $\mathrm{K}^{+}$- the origin of which may involve infiltration of both industrial and urban wastewater (Hudak and Sanmanee 2003; Esteller et al. 2012). Factor II likely represented the process of interaction between groundwater and silicate materials present in the aquifer. High concentrations of $\mathrm{Si}$ and $\mathrm{Na}^{+}$, as well as higher temperatures, would indicate a longer residence time, which would allow for longer interaction between water and solids, as well as a higher dissolution rate of less soluble minerals, for example, feldspar and mica (Appelo and Potsma 2005).

Figure 14 shows the relationship of factor loadings to groundwater variables and how variables are related to the processes of water-rock interaction (upper quadrants). On the other hand, variables characteristic of urban pollution sources were located in the lower quadrants. Therefore, factors I and II presumably indicated contamination and natural processes, respectively.

\section{Conclusions}

The central portion of the Toluca Valley aquifer is characterized by a rapid urbanization process which was facilitated by an industrialization process in the 1980s. The demand for groundwater has increased as a consequence of industrial development and population growth. In the municipality of Toluca and the sector in which the industrial zone is located, well density is high and the groundwater extraction rate is calculated as being $134 \mathrm{Mm}^{3} /$ year.

Due to intensive exploitation, some changes can be seen in groundwater flow direction in the central portion of the Toluca Valley aquifer. Such changes are primarily influenced by water extraction in the NE sector, where the industrial zone is located. In addition, temporal evolution of groundwater levels makes it possible to calculate declines of more than $30 \mathrm{~m}$ for the period 1968-2010. A drawdown cone has formed as a result of this decline in groundwater level, which encompasses part of the sector where the municipality of Toluca is located.

Groundwater hydrochemistry in the central portion of the Toluca Valley aquifer has not shown any significant changes over the years; nevertheless, concentrations of certain chemical elements, including $\mathrm{Cl}^{-}, \mathrm{NO}_{3}{ }^{-}$ and $\mathrm{SO}_{4}{ }^{2-}$, can be identified mainly in the industrial zone, although they do not exceed water quality standards for human consumption and use. High concentrations of $\mathrm{Cl}^{-}$and $\mathrm{NO}_{3}{ }^{-}$are also present in the sector where the urban zone is concentrated.

During the 2010 sampling campaign, two wells (San Antonio Abad and Santa María Totoltepec) showed characteristics that differed from wells in the remainder of the area. Since these wells are located in the industrial zone and close to the most extensive fissure, the industrial zone could be considered a focus of contamination, 
and fissuring may have facilitated the infiltration of contaminants.

Lastly, based on variations in flow direction and the appearance of a drawdown cone, it can be said that changes are evident in the hydrodynamics of the central portion of the Toluca Valley aquifer, although such changes in hydrochemistry only appear to be reflected at certain points, in some wells located near fissures.

Thus, it would be important to consider conducting studies for evaluating some of the parameters that serve as indicators of contamination-including $\mathrm{NO}_{3}{ }^{-}, \mathrm{Cl}^{-}$, and $\mathrm{SO}_{4}{ }^{2-}$, in addition to boron, which has already been used as an indicator of contamination in urban areas.

Acknowledgments The authors wish to express their gratitude to the Universidad Autonoma del Estado de México (Project $2600 / 2008$ U) for providing financial support. Particular thanks are given to Comision Nacional del Agua (CONAGUA) for their helpful technical support. The work by M.A. Martín del Campo conducted for this research was carried out with the financial support of Consejo Nacional de Investigación y Ciencia (CONACyT), for the period of the research visit to the Universidade de São Paulo.

\section{References}

APHA, AWWA, WEF (2005) Standard methods for the examination water and wastewater. 21th edn. APHA, AWWA, WEF. Washington, D.C.

Appelo, C. A. J., \& Potsma, D. (2005). Geochemistry, groundwater and pollution (2nd edn). Rotterdam: Balkema.

Ariel y Consultores (1996) Estudio de simulación hidrodinámica y diseño óptimo de las redes de observación de los acuíferos de Calera, San Luis Potosí y Toluca (Tomo 3: Acuífero de Toluca) CNA (Comisión Nacional del Agua) México D.F.

Bathrellos, G. D., Skilodiumou, H. D., Kelepertsis, A., Alexakis, D., Chrisanthaki, I., \& Archonti, D. (2007). Environmental research of groundwater in the urban and suburban areas of Attica region, Greece. Environmental Geology, 56, 11-18.

Bense, V. F., Van den Berg, E. H., \& Van Balen, R. T. (2003). Deformation mechanisms and hydraulic properties of fault zones in unconsolidated sediments, The Netherlands. Hydrogeology Journal, 11(3), 319-332.

Borja, R., \& Rodríguez, R. (2004). Aquifer vulnerability changes due to faults and riverbeds in Salamanca, Guanajuato, Mexico. Geofisica Internacional, 43(4), 623-628.

Boulding, J. R. (1995). Practical handbook of soil, vadose zone, and ground-water contamination. Assessment, prevention and remediation. Boca Raton: Lewis.

Calderhead, A. L., Therrien, R., Rivera, A., Martel, R., \& Garfias, J. (2011). Simulating pumping-induced regional land subsidence with the use of InSAR and field data in Toluca Valley, Mexico. Advances in Water Resources, 34, 83-97.

Carlson, M. A., Lohse, K. A., McIntosh, J. C., \& McLain, J. E. T. (2011). Impacts of urbanization on groundwater quality and recharge in a semi-arid alluvial basin. Journal of Hydrology, 409, 196-211.

Carrera-Hernández, J. J., \& Gaskin, S. J. (2007). The basin of México aquifer system: regional groundwater level dynamics and database development. Hydrogeology Journal, 15, $1577-1590$

Carrillo-Rivera, J. J., Cardona, A., Huizar-Álvarez, R., \& Graniel, E. (2008). Response of the interaction between groundwater and other components of the environment in México. Environmental Geology, 55, 303-319.

CCRECRL (Comisión Coordinadora para la Recuperación Ecológica de la Cuenca del Río Lerma). (1993). Atlas Ecológico de la Cuenca Hidrográfica del río Lerma. México: Gobierno de Estado de México.

Choi, B., Yun, S., Yu, S., Lee, P., Park, S., Chae, G., et al. (2005). Hydrochemistry of urban groundwater in Seoul, South Korea: effects of land use and pollutant recharge. Environmental Geology, 48, 979-990.

CONAGUA (Comisión Nacional del Agua) (2002). Determinación de la disponibilidad de agua en el Acuífero del Valle de Toluca, Subdirección General Técnica. Gerencia de Aguas Subterráneas, Subgerencia de Evaluación y Modelación Hidrogeológica. CONAGUA México D.F. Technical report.

CONAGUA (Comisión Nacional del Agua) (2005). Sistema Cutzamala: Agua para millones de Mexicanos. Gerencia Regional de Aguas del Valle de México y Sistema Cutzamala. CONAGUA México D.F. Technical report.

CONAGUA (Comisión Nacional del Agua) (2009). Actualización de la disponibilidad media anual de agua subterránea. Acuífero (1501) Valle de Toluca, Estado de México. Subdirección General Técnica. Gerencia de Aguas Subterráneas, Subgerencia de Evaluación y Ordenamiento de Acuíferos. CONAGUA México D.F. Technical report.

Corniello, A., Ducci, D., \& Ruggieri, G. (2007). Areal identification of groundwater nitrate contamination sources in periurban areas. Journal Soils and Sediments, 7(4), 159-166.

Dash, J. P., Sarangi, A., \& Singh, D. K. (2010). Spatial variability of groundwater depth and quality parameters in the National Capital territory of Delhi. Environmental Management, 45, 640-650.

ESRI Environmental Systems Research Institute Inc. (1999). Arc View 3.2. User's guide.

Esteller, M. V., Rodríguez, R., Cardona, A., \& Padilla-Sanchez, L. (2012). Evaluation of hydrochemical changes due to intensive aquifer exploitation: study cases from Mexico. Environmental Monitoring and Assessment, 184, 5725-5741.

Esteller, M. V., \& Andreu, J. M. (2005). Antropic effects on hydrochemical characteristics of the Valle de Toluca aquifer (central Mexico). Hydrogeology Journal, 13, 378-390.

Esteller, M. V., \& Díaz-Delgado, C. (2002). Environmental effects of aquifer overexploitation: a case study in the Highlands of Mexico. Environmental Management, 29(2), 266-278.

Fonseca Ortiz, C. R., Díaz-Delgado, C., Hernández Téllez, M., \& Esteller Alberich, M. V. (2013). Urban water demand in Mexico: spatial modeling based on geographic information system. Interciencia, 38(1), 17-25.

Foster, S., Hirata, R., \& Howard, K. (2011). Groundwater use in developing cities: policy issues arising from current trends. Hydrology Journal, 19, 271-274.

GEM Gobierno del Estado de México (2005a) Plan de Desarrollo Regional del Valle de Toluca. 118pp. 
GEM Gobierno del Estado de México (2005b). Plan Municipal de Desarrollo Urbano de Toluca. 451pp.

Golden Software Inc. (1997). Surfer V 6 Contouring and 3D surface mapping for scientist and engineers. User's guide. Colorado: Golden.

Gutiérrez-Carrillo, N., Palacios-Vélez, E., Peña-Díaz, S., \& Palacios-Vélez, O. (2002). Stages for sustainable uses of the Queretaro Valley aquifer. Agrociencia, 36, 1-10.

Healy, R. W. (2010). Estimating groundwater recharge. Cambridge: Cambridge University Press.

Howard K.W.F. (2007) Urban groundwater: meeting the challenge. IAH Select paper Series 8. Oxford: Taylor and Francis.

Hudak, P., \& Sanmanee, S. (2003). Spatial patterns of nitrate, chloride, sulfate, and fluoride concentrations in the Woodbine aquifer of North-Central Texas. Environmental monitoring and assessment., 82, 311-320.

IMTA (Instituto Mexicano de Tecnología del Agua). CONAGUA (Comisión Nacional del Agua) (2009). Inventario de Aprovechamientos de agua subterránea en el el acuífero del Valle de Toluca. CONAGUA, México, D.F. Technical report.

INEGI (Instituto Nacional Estadística Geografía e Informática) (2009) Censos económicos 2009. Resultados generales INEGI México, D.F. www.inegi.gob.mx. Accessed 4 Jan 2011.

INEGI (Instituto Nacional Estadística Geografía e Informática) (2004) Delimitación de las zonas metropolitanas de México SEDESOL-CONAPO-INEGI México, D.F. www.inegi. gob.mx/est/contenidos(espanol/otras_zonas_met.pdf Accessed 4 Jan 2011.

INEGI (Instituto Nacional Estadística Geografía e Informática). (2006). Sistema para la Consulta de Información Censal (SCINCE). México: INEGI.

INEGI (Instituto Nacional Estadística Geografía e Informática) (2010) Censo Nacional de Población y Vivienda, 2010. INEGI, México. D.F. Disponible en http://www.inegi.org.mx/ Sistemas/temasV2/Default.aspx?s=est\&c=17484. Accessed 4 Jan 2011.

Jeong, C. H. (2001). Effect on land use and urbanization on hydrochemistry and contamination of groundwater from Taejon area, Korea. Journal of Hydrology, 253, 194-210.

Jiao, J. J., Leung, C., \& Ding, G. (2008). Changes to the groundwater system, from 1888 to present in a highly-urbanized coastal area in Hong Kong, China. Hydrogeology Journal, 16, 1527-1539.

Jiménez, B., Torregrosa, M. L., \& Aboites, L. (2010). El agua en México: cauces y encauces. México: Academia Mexicana de Ciencias.

Jin, Z., Chen, Y., Wang, F., \& Ogura, N. (2003). Detection of nitrate source in urban groundwater by isotopic and chemical indicators, Hsangzhou City, China. Environmental Geology, $45,1017-1024$.

Kontogianni, V., Pytharouli, S., \& Stiros, S. (2007). Groundwater subsidence, Quaternary faults and vulnerability of utilities and transportation network in Thessaly, Greece. Environmental Geology, 52, 1085-1095.

Lerner, D. N. (2002). Identifying and quantifying urban recharge: a review. Hydrogeology Journal, 10, 143-152.

Lesser y asociados, S.A. (1984) Actividades geohidrológicas en el Alto Lerma. Informe para la Dirección General de
Construcción y Operación Hidráulica. Contrato 4-33-1-677. México.

Leung, C., Jiao, J. J., Malpas, J., Chan, W., \& Wang, Y. (2004). Factors affecting the groundwater chemistry in highly urbanized coastal area in Hong Kong: an example from the MidLevels area. Environmental Geology, 48, 480-495.

Liu, C. W., Lin, K. H., \& Kuo, Y. M. (2003). Application of the factor analysis in the assessment of groundwater quality in a blackfoot disease area in Taiwan. The Science of the Total Environment, 313, 77-89.

Mejía, J. A., Rodríguez, R., Armienta, A., Mata, E., \& Fiorucci, A. (2007a). Aquifer vulnerability zoning, an indicator of atmospheric pollutants input? Vanadium in the Salamanca aquifer, Mexico. Water, Air \& Soil Pollution, 185(1-4), 95-100.

Mejía, L., Murillo S., \& Reyes J. (2007b). Plan de manejo del Valle de Toluca. Cuenca y Acuífero. Problemática y Perspectivas. CONAGUA (Comisión Nacional del Agua), Subdirección General de Programación; Dirección Local Estado de México.

Morris, B. L., Seddique, A. A., \& Ahmed, K. M. (2003). Response of the Dupi Tila aquifer to intensive pumping in Dhaka, Bangladesh. Hydrogeology Journal, 11, 496503.

Naik, P. K., Tambe, J. A., Dehury, B. N., \& Tiwari, A. N. (2008). Impact of urbanization on the groundwater regime in a fast growing city in central India. Environmental Monitoring Assessment, 146, 339-373.

Ramos-Leal, J. A., Noyola-Medrano, C., \& Tapia-Silva, F. O. (2010). Aquifer vulnerability and groundwater quality in mega cities: case of the Mexico Basin. Environmental Earth Sciences, 61, 1309-1320.

Rudolph, D. L., Sultan, R., Garfias, J., \& McLaren, R. G. (2005). Significance of enhanced infiltration due to groundwater extraction on the disappearance of a headwater lagoon system: Toluca Basin, Mexico. Hydrogeology Journal, 14, 115-130.

Secretaría de Industria y Comercio (1963) VII Censo General de Población 1960. Dirección General de Estadística. México D.F.

Vázquez-Suñé, E. (2003) Urban groundwater. Barcelona City case study. Ph.D. thesis. Universidad Politécnica de Cataluña. http://www.tdx.cat/bitstream/handle/10803/6232/ 01Evs01de01.pdf;jsessionid. Accessed 22 Jan 2011

Vázquez-Suñé, E., Carrera, J., Tubau, I., Sanchez-Vilá, X., \& Soler, A. (2010). An approach to identify urban groundwater recharge. Hydrology and Earth System Science, 14, 20852097.

Vázquez-Suñé, E., Sánchez-Vila, X., \& Carrera, J. (2005). Introductory review of specific factors influencing urban groundwater, an emerging branch of hydrogeology, with reference to Barcelona, Spain. Hydrogeology Journal, 13(3), 522-533.

Waterloo Hydrogeologic (1999). User's guide of AquaChem (v 3.7). Waterloo, Ontario, Canada: Waterloo Hydrogeologic.

Wolf, L., Eiswirth, M., \& Hötzl, H. (2006). Assessing sewergroundwater interaction at the city scale based on individual sewer defects and maker species distributions. Environmental Geology, 49, 849-857. 